
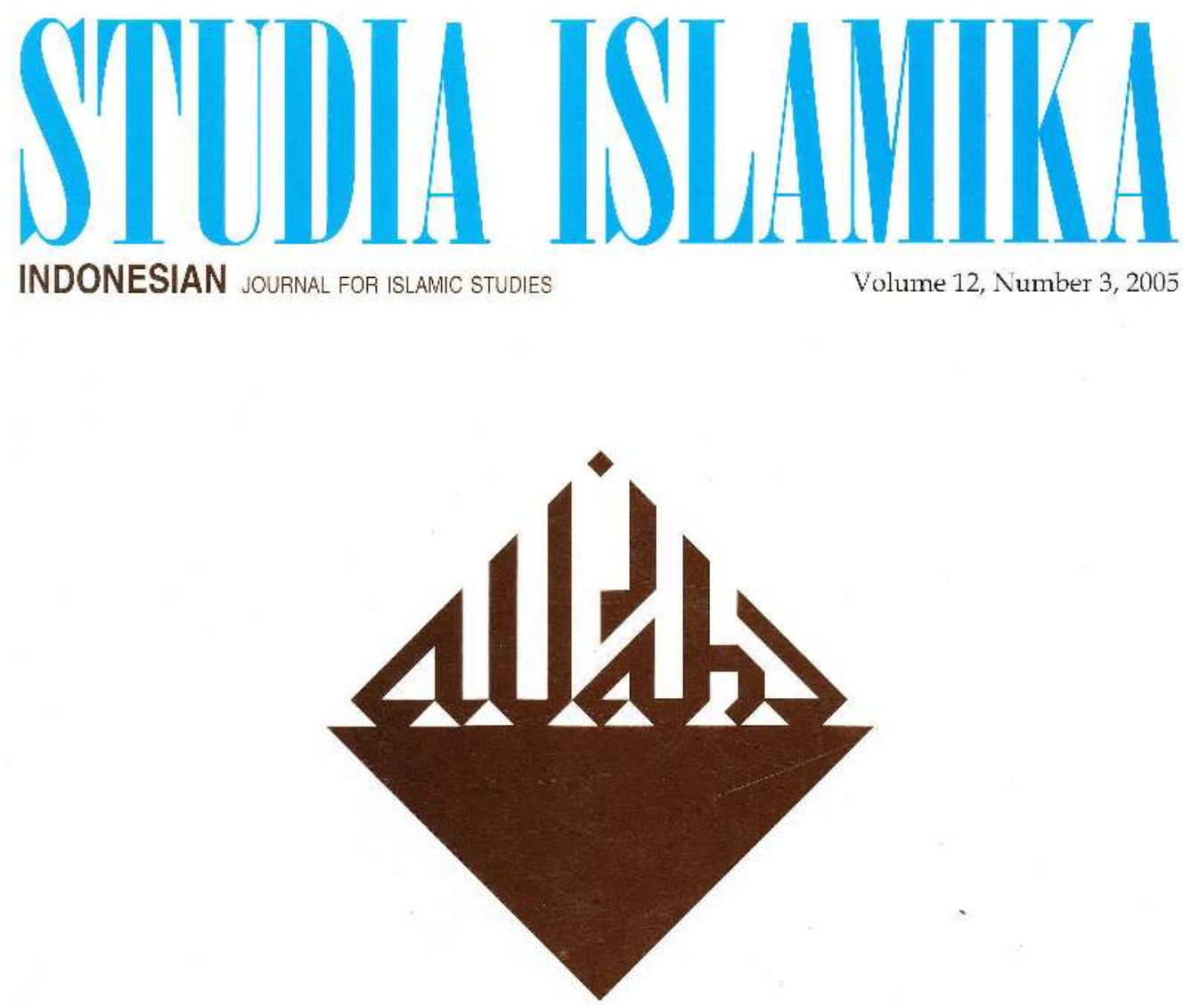

The Rupture of Young Muslim

INTELLIGENTSIA IN THE MODERNIZATION OF INDONESIA

Yudi Latif

MEDIA AND ISLAMISM

IN POST-NEW ORder INDONESIA:

THE CASE OF SABILI

Syamsul Rijal 


\section{STIDLA ISLAMIKL \\ Indonesian Joumal for Islamic Studies \\ Vol. 12, no. 3, 2005}

EDITORIAL BOARD:

M. Quraish Shilab (UIN Jakarta)

Taufik Abdullah (LIPI Jakarta)

Nur A. Fadhil Lubis (IAIN Sumatra Utara)

M.C. Ricklefs (Melboume University)

Martin van Bruinessen (Utrecht University)

John R. Bowen (Washington University, St. Louis)

M. Atho Mudzhar (IAIN Yogyakarta)

M. Kamal Hasan (International Islamic University, Kuala Lumpur)

\section{EDITOR-IN-CHIEF}

Azyumardi Azra

\section{EDITORS}

Saiful Mujani

Jamhari

Jajat Burianuddin

Fu'ad Jabali

Oman Fathurahman

ASSISTANT TO THE EDITORS

Heni Nuroni

ENGLISH LANGUAGE ADVISOR

Cheyne Scott

\section{ARABIC LANGUAGE ADVISOR}

Muhbib AbduI Wahab

COVER DESIGNER

S. Prinka

STUDIA ISLAMIKA (ISSN 021.5-0492) is a journal published by the Center for the Study of Islam and Society (PPIM) UIN Syarif Hidayatullah, Jakarta (STT DEPIEN No. 129/SK/DITJEN/PPG/STT/1976) and sponsored by the Australia-Indonesia Institute (AII). It specializes in Indonesian lslamic studies in particular, and South-east Asian Islamic Studies in general, and is intended to conmunicate original researches and current issues on the subjecl. This journal warmly welcomes contributions from scholars of related disciplines.

All articles published do not necessarily represent the views of the joumal, or other institutions to which it is affiliated. They ure solely the views of the authors. The articles contained in this journal have been refereed by the Board of Editors.

STUDIA ISLAMIKA has been accredited by The Ministry of National Education, Repubic of Indonesia as an acudentic journal (SK Dirjen Dikti No. 23a/DIKTI/2004). 


\title{
Syamsul Rijal
}

\section{Media and Islamism in Post-New Order Indonesia: The Case of Sabili}

\begin{abstract}
Abstraksi: Jatuhnya rejim Soeharto pada Mci 1998 menjadi awal dari perubahan penting di hampir semua aspek dalam kehidupan bangsa Indonesia. Salah satu pcrubahan itu adalah tampilnya kelompok-kclompok keagamaan Muslim yang mengedcpankan satu corak pemikiran dan praktik keagamaan Islamisme - bahwa Islam tidak hanya untuk kehidupan manusia dengan Tuhan tapi juga mengatur kehidupan sosial-politik dan kenegaraan. Kelompok Muslim Islamis ini, juga disebut Muslim radikal, menjadikan alam keterbukaan dan kebebasan pasca Mei 1998, era reformasi, sebagai arena untuk menunjukkan jati diri mereka.

Pada tingkat institusi, scjak cra reformasi telah berdiri ormas-ormas Islam antara lain Hizbuttahrir, Front Pembela Islam (FPI), Laskar Jihad (LJ), Ikhwanul Muslimin (IM), dan Majelis Mujahidin Indonesia (MMI). Sebagai kelompok Istamis, ormas-ormas ini mengusung tema pencgakan syari'ah Islam dalam kehidupan publik Indoncsia, anti-Barat, dan karenanya percaya sepenuhnya bahwa Islam merupakan jawaban terhadap semua persoalan yang berkembang di Indonesia, yang tclah dilanda krisis ekonomi betkepanjangan. Di samping ormas-ormas Islam di atas, munculnya gerakan Islamis ini juga ditandai tumbuhnya sejulmah media cetak yang menyebarka pemikiran Islam bercorak Islamis. Dan salah satu majalah berhaulan Isamis terlemuka di Indonesia masa reformasi ini adalah majalah Sabili.
\end{abstract}

Artikcl ini menghadirkan kajian tentang majalah Sabili. Majalah tersebut sebcnarnya terbit pertama pada 1980-an, tapi hanya satu edisi karena alasan politik represif Orde Baru. Setclah terbit kembali pada 1993 dan berlangusng hingga tahun 2000, juga dengan alasan yang tidak jauh berbeda. Tctbit sebagai majalah Islamis olch kelompok gerakan keagamaan berbasis 
kampus (tarbiyah), majalah Sabili jelas secara ideologis bertentangan dengan pemcrintah Orde Baru Indonesia. Majalah ini difhat sebagai wujud gerakan Islam dan karenanya dicatat sebagai anti ideologi negara Pancasila. Baru pada cra reformasi scjak 1998, Sabili kembali terbit dengan ijin resmi dari negara.

Bersamaan dengan itu, manajcmen majalah juga berubah. Saat pertama kali muncul, Sabili bcrada di bawah satu institusi Kelompom Telaah dan Amaliah Islami (KTA), satu kelompok tarbiyah berbasis di Universitas Indonesia (UI). Lcmbaga penerbit ini pada era tcformasi beralih menjadi P.T. Bina Media Sabili. Ini menunjukkan bahwa Sabili megalami pembahan sccara manajamen, mcski mereka yang duduk pada jajaran redaksi rekatif sama. Scjak itulah, Sabili tcrus berkembang dan diterima secara luas oleh publik Muslim Indonesia. Dibanding majalah-majalah lain, Sabili termasuk yang terdepan dengan jumlah cetak mencapai rata-rata di atas $80.000 \mathrm{cksem}$ plar pada tahun 2000-an ini.

Aspck utama berikutnya yang menjadi fokus perhatian artikel ini adalah unsur-unsur Islamis dalam Sabili. Dan, memang, Sabili jelas dirancang dalam kerangka ideologi keagaman Islamis. Hal ini bisa dilihat misalnya dari jajaran redaksi, di mana sebagian besar mereka berasal dari kclompok kcagamaan kampus (tarbiyah) yang memang tclah lama mongedepankan agenda-genda Islamis. Di samping itu, mereka berafiliasi dengan ormas-ormas Islam bcrhaluan serupa, scperti Lembaga Dakwah Kampus (LDK), Pelajar Islam Islam Indonesia (PII), Pcsantren Hidayatullah, dan LIPIA, satu lcmbaga pendidikan bahasa Arab yang bcrafiliasi (juga didanai) Pemerintahan Arab Saudi. Begitu pula hal yang sama bisa dilihat dari jajaran penulis atau kontributor, di mana Sabili lcbih banyak mengundang mereka yang mengedepankan tema-tema Islamis.

Lcbih lanjüt, unsur Islamisme juga bisa dilihat sccara jelas dari wacana yang diketengahkan Sabili. Analisa atas muatan rubrik yan tersedia menunjukkan bahwa isu-isu dan agenda-agenda Islamisme merupakan perhatian utama majalah Sabili. Isu-isu dan agenda-agenda Islamisme tersebut ditumuskan antara lain ke dalam dukungan Sabili atas pencrapan syari'ah Islam dalam kehidupan sosial-politik dan kenegaraan Indonesia. Bagi Sabili, pencrapan syari'ah merupakan solusi efektif atas permsalahan yang melanda Indonesia. Isu lain yang menjadi perhatian Sabili adalah sentimen anti-Barat (baca: Amcrika Serikat), demokrasi, presiden wanita, dan lain sebagainya. Pada saat yang sama, Sabili secara tegas menyatakan perang terahadap kclompok Muslim yang dianggap mendukung Barat, khususnya mereka yang mengedepankan agenda toleransi dan pluralisme. 
Syamsul Rijal

\section{Media and Islamism in Post-New Order Indonesia: The Case of Sabili}

خحلاصة :كان سقوط نظام سو مارتو في مايو 1998 بلاية للتغيرات الهامة في مسظم

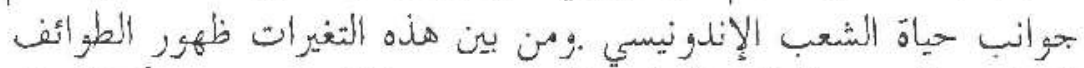

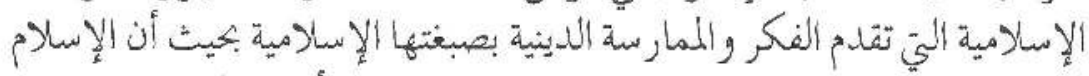

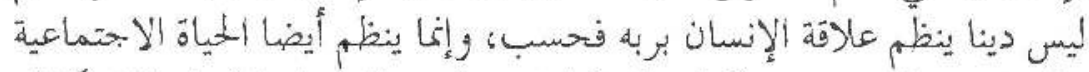

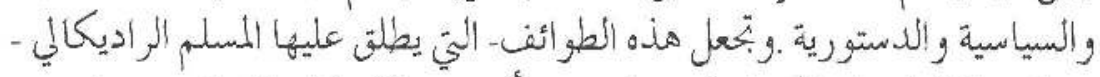

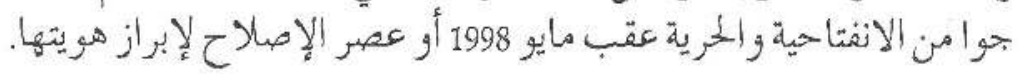

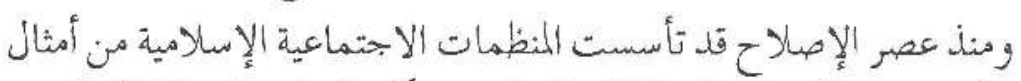

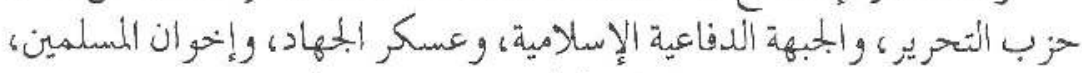

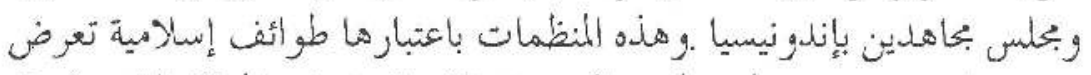

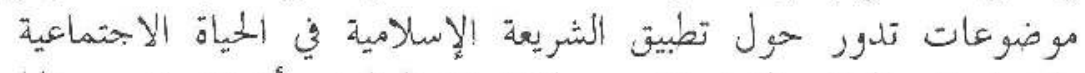

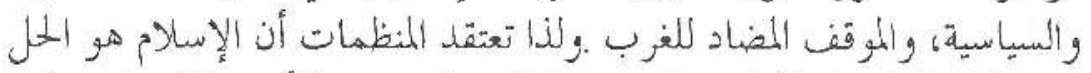

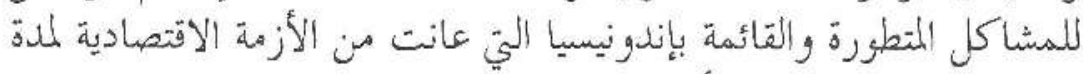

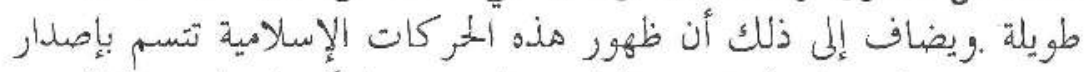

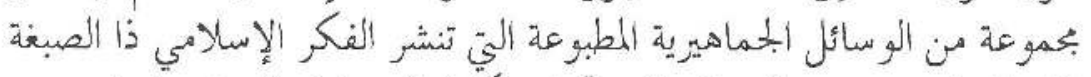

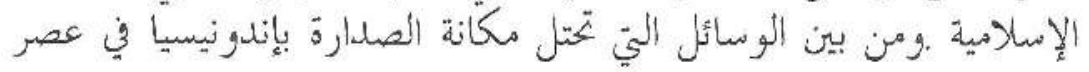

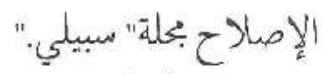

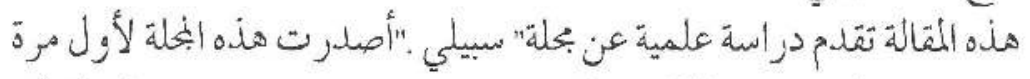

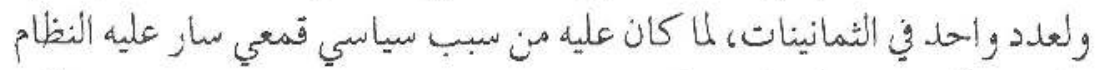

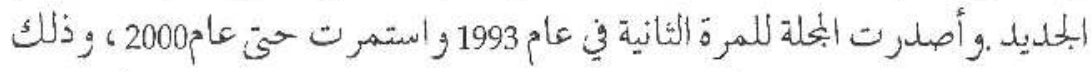

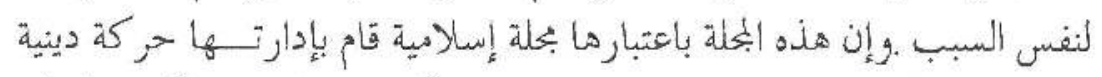

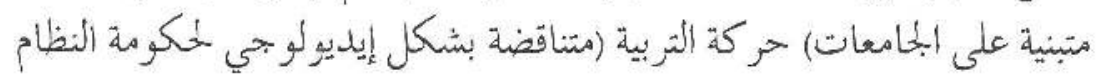




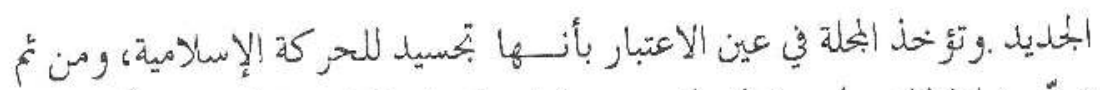

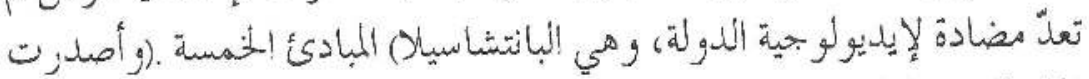

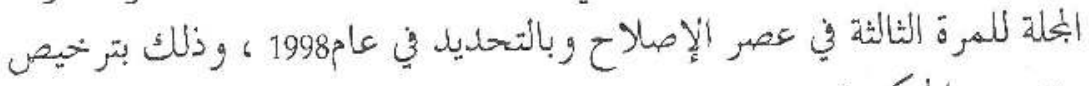

$$
\text { رسمي من الحكومة. }
$$

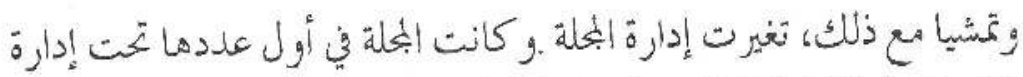

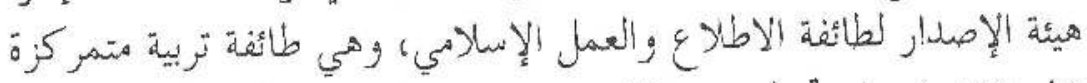

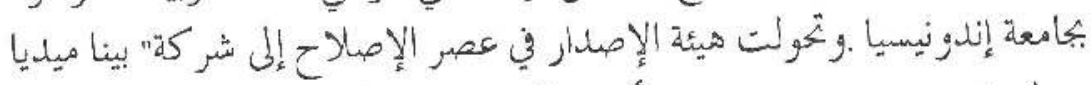

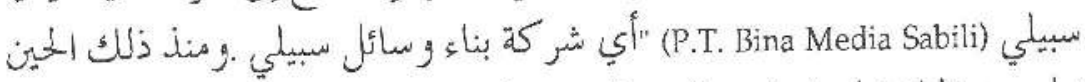

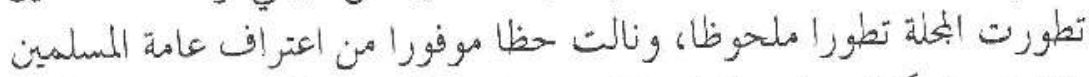

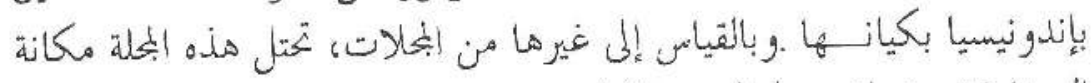

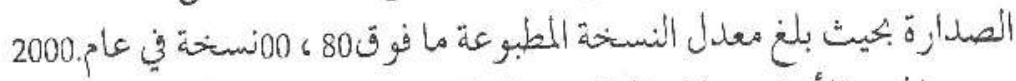

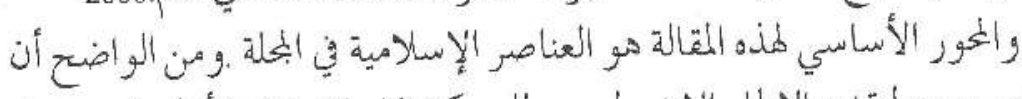

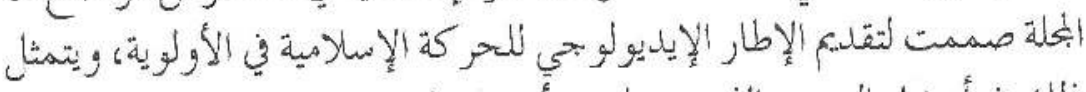

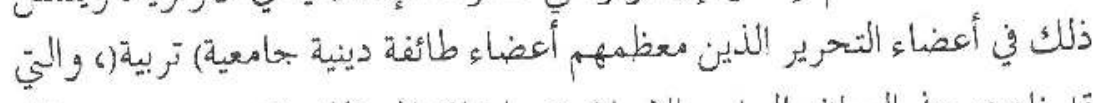

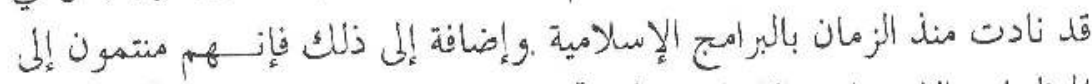

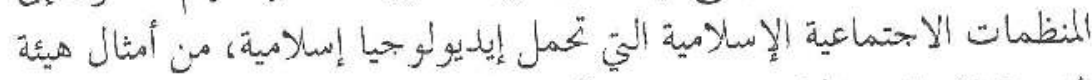

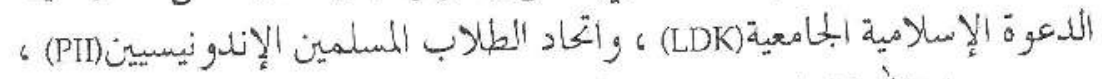

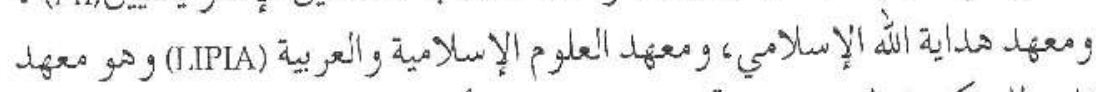

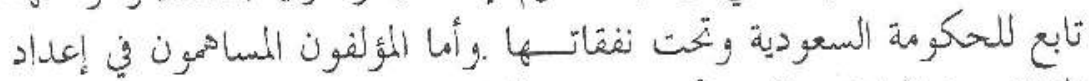

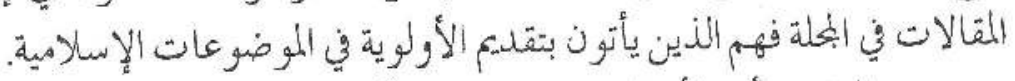

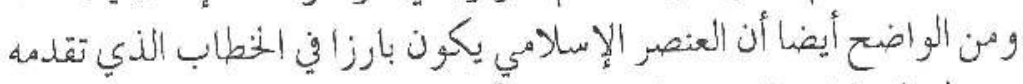

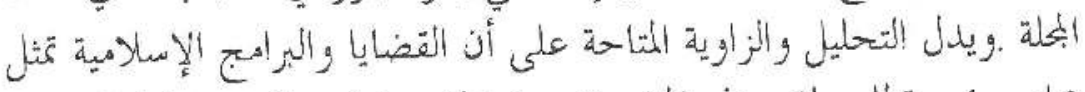

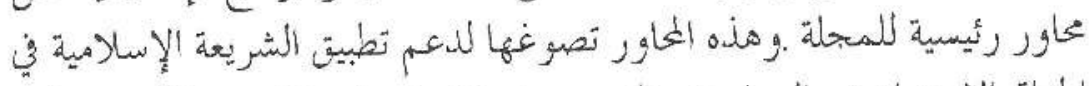

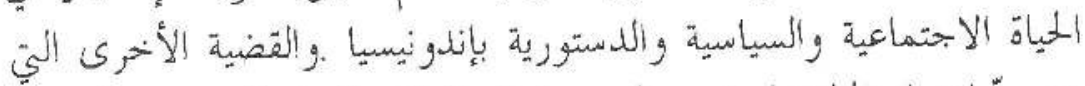

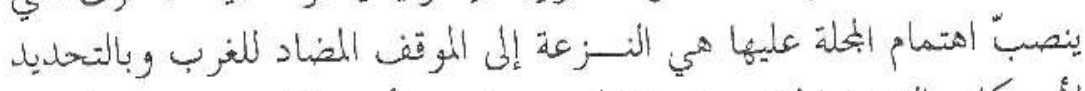

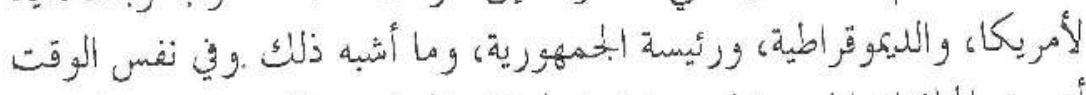

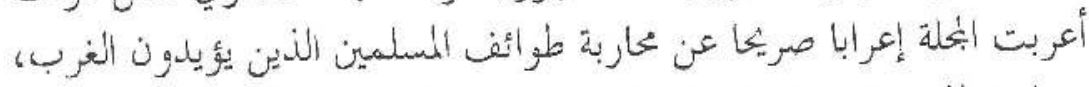

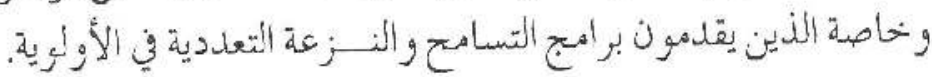


$\mathrm{T}$ his article examines the Islamist issues presented by the Sabili magazine in post-New Order Indonesia from 1998 to 2004. This study is mainly inspired by the resurgence of Islamism as a consequence of political liberalization that resulted from the fall of Soeharto in May 1998. The press freedom permitted by president Habibic has given Islamic media such as the Sabili magazine the opportunity to operate relatively freely, unlike the restrictions faced during the New Order era. Sabili magazine, as the object of this study, has for sometime been a popular Islamic magazine among Muslim readers in Indonesia.

A study of the resurgence of Islamism in post-Soeharto Indonesia would not be comprehensive without considering Sabili; this magazine constitutes one of the most prominent Islamist magazines of the post-Soeharto era. This writing examines the content of the magazine and the current Islamist issues it presents in dealing with contemporary Indonesian and international issues. This study further aims to comprehend the characteristics of Islamism as represented in this magazine.

\section{Islamism in the Post-New Order Era}

The demise of President Soeharto after more that three decades in power was followed by unprecedented political freedom, especially for Muslim groups who in the past had been severely restricted in the public sphere. 'As a result, Islamism flourished in as Muslims were now able to freely express and articulate their ideas in the public domain without fear of reprisals. Furthermore, the emergence of Islamist movements in the Post-New order era was made possible by what Marty and Appleby call "the delayed psychological responses" to the authoritarian New Order political system. ${ }^{2}$

There were at least four important implications of the fall of the New Order regime and the freedoms that followed. First is the establishment of numerous Islamic political parties that adopted Islam as their foundational basis, thus replacing the Pancasila, Indonesia's state ideology. It should be noted that between May and October in 1998, 42 parties which could be classified as 'Islamic' (in the sense that they used Islamic symbols or Islam as their ideology) were established. ${ }^{3}$ Two parties, the United Development Party (PPP) and the Crescent Star Party (PBB), insisted that Articlc 29 of the 1945 Constitution be amended to reinsert the famous "seven words" (dengan kewajiban melaksanakan syariat Islam bagi pemeluknya [with the obligation to carry out shari'ah for its adherents]. These words, they believed, would officially provide shari'ah with the constitutional status within the Indonesian national legal system. This proposal to reintroduce the clause, which would have required Indonesian Muslims to apply 
shari'ah, has been unsuccessful on three separate occasions, that is at the annual sessions of the Pcople's Consultative Assembly (Majelis Permusyawaratan Rakyat, or MPR) in 2000, 2001, and 2002. In the 2002 annual session, the MPR decided not to amend Article 29 of the 1945 Constitution. However, Islamic parties continue to advocate the formal application of shari'ah.

Second is the growing demand for the formal implementation of shari' ah in some regions of Indonesia. Aceh was the first province to demand the application shari'ah. In fact the application of shari'ah in this region first became evident when in November 1999 a young man accused of committing adultery was punished by being whipped one hundred times in public. Similarly in South Sulawesi, there are increasing demands for the application of shari'ah. Abdul Aziz Qahhar Muzakkar, chief of the Preparation Committee for the Application of Shari'ah (KPPSI) in South Sulawesi, has said that the special autonomy status granted to Aceh, including the implementation of shari'ah, has paved the way for other provinces to secure the same status. Thus, South Sulawesi should also be granted special autonomy status. Moreover, it has been known that at least twenty out of twenty-four heads of districts (kotamadya/kabupaten) in that province have expressed their willingness to apply shari ${ }^{\prime}$ ah in their own arcas. ${ }^{4}$

The third is the emergence of Muslim groups considered by many as radical in their actions or ideology (or both), such as the Lasykar Jihad (Jihad Troops), Front Pembela Islam (FPI, or Islamic Defenders Front), Hizbut Tahrir (Party of Liberation), and the Majelis Mujahidin Indonesia (the Indonesian Mujahidin Council), throughout the country. FPI, for example, has in the past carried out radical and violent attacks on discotheques, nightclubs, and other places of entertainment in the name of amar ma'ruf wa nahy munkar (enjoining good and prohibiting evil), in order to eradicate all sorts of religiously prohibited practices such as gambling, the consumption of alcohol, and prostitution. In so doing, they see themselves as the torch-bearers in the application of shari'ah in Indonesia. In their efforts, they are frequently confronted by other groups of people, including Muslims, who reject their claims and radical ways. ${ }^{5}$

According to Effendy, the emergence of these organizations was a response to the socio-religious and political circumstances which evolved during the period of transition, which in their view did not seem in accord with Islamic values or Muslim interests. The inability of the state to administer effectively and solve pressing problems that concern the lives of many Muslims (for example, socio-religious conflicts, law enforcement on gambling and prostitution, and regulation of alcoholic beverages) has triggered the cmergence of these Islamist groups. Similarly, the foreign 
policy of the United States towards the Islamic world, which is often perceived as uneven-handed, discriminatory, and unjust, especially concerning the Palestinian nation and the invasion of Iraq, has also contributed to their emergence. ${ }^{6}$

The last consequence of the political transition is the increasing popularity of Islamist magazines, most notably Sabili, which has a considerably large readership in Indonesia. ${ }^{7}$ This bi-monthly magazine, which was published underground during the New Order era, currently publishes more than 100,000 copies cach edition. Sabili used to focus more on da'wah media, but it now appears to be more concerned with promoting political Islam, typically from the viewpoint of hardliners. Some of its published opinions are clearly seen as advocating support for the formal application of shati'ah. It repeatedly argues in editions that because the Indonesian national law is man-made and not divine, it can never earn the people's respect. Sabili asserts that the answer to Indonesia's legal crisis is to return to the way of God, that is, a return to the application of shari' ah. This magazine further targets Christians and the West (America), pounding them with harsh criticism. It is worth noting also that the revival of Sabili inspired the emergence of other magazines such as Saksi, Tarbawi, Ummi, Annida, and so forth.

Since the main concern of this section is the public sphere and Islamic Print media in the post-New Order era, I will not provide an in-depth description of the Islamic militant groups or the development of the implementation of shari'ah in a regional context as such topics have been elaborated on elsewhere and are readily available in numerous other current works. ${ }^{8}$ The main point to be made here is that in the era of political openness of Indonesia, Islamist groups have found momentum to accelerate their movements. Moreover, there has been significant support for Islamism in Indonesian society. If a willingness to implement shari'ah is an indication of Islamism, the rising trend of Islamism in Indonesia seems to be strong. In November 2002, the Centre for the Study of Islam and Society (PPIM) Syarif Hidayatullah Jakarta State Islamic University conducted a survey on Indonesian Muslims' attitudes toward Islamism. The survey discovered that many Indonesian Muslims appear to be Islamist on the broadest level, that is, they believe that laws should somehow be basically in accord with Islam. At the general level of assessment, more than two-thirds ( 67 percent) of Indonesian Muslims appear to express support for an Islamic state. An even larger percentage (71 percent) says specifically that the government should enforce shari'ah on Indonesian Muslims. However, when given the more specific choices of Islamic law such as amputating the hands of thieves and restricting the public role of women, 
support for Islamism drops sharply from $71 \%$ to $46 \%$. Furthermore, the survey found that at the mass support for Islamism in Indonesia is a rural phenomenon rather than an urban one?

There have been many analyses provided by intellectuals on the root causes of the emergence of radical Islamism in Indonesia. Some of them emphasize the intemal factors while others focus on external factors ${ }^{10}$. The conclusion that could be drawn from their views is that Islamic radicalism in Indonesia is rooted in four major factors: political repression, poor governance, global awareness, and Arabia. ${ }^{11}$ However, what is missing from their discussion is how the process of radicalization occurs in the public sphere, particularly media. In social movement theory, the media is regarded as an important means of attracting people to a certain ideology and motivating them to take political action. The nature of media discourse influences the construction of collective action frames by social movements. ${ }^{12}$ The wide spread of Islamist ideas through the media could in fact influence society to accept such ideas. Therefore, any analysis of Islamic radicalism in contemporary Indonesia should include Islamic media as one of the important elements.

\section{The Rising Public Sphere and Print Islam}

The growth of media - especially Islamic magazines - in the post New Order era has been the result of press freedoms established by President B.J. Habibie. The downfall of Soeharto triggered a flurry of policy changes towards the print media. Habibie appointed Lieutenant-General Muhammad Yunus Yospiah as Information Minister. He promised a review of press regulations and legislations, and rescinded an unpopular 1984 ministerial regulation (Permenpen 01/1984) under which the Minister could revoke a publication's permit (SIUPP), as was done so dramatically in the July 1994 bans. Instead, Yunus Yospiah's Regulation (Permenpen 01/1998) ruled that publishers would be taken to court for breaching permit conditions. He announced his intention to streamline the complex procedures for obtaining a SIUPP, to eliminate opportunities for corruption. ${ }^{13}$ As reported by Hill and Sen, within Yunus Yospiah's first six months of office, nearly 500 new permits had been issued, opening the industry to an unprecedented level of competition. ${ }^{14}$ Sabili itself obtained a SIUPP in 1998.

Freed from the constraints of state censorship and propaganda, all segments of the media community including Islamic media have moved quickly toward diversity and pluralism. In this context, religious authority has been fragmented among Muslims who struggle and compete for what Dale F. Eickelman and James Piscatory call "the interpretation of symbols and control of the institutions". ${ }^{15}$ What is more apparent in the post Soe- 
harto era is the religious debates between Islamists and liberal Muslims in the media. Such debates are more likely the continuation of debates between what Liddle called scripturalist and subtantialist Muslims in the New Order era. However, the current debates seem to be more intense and advanced.

The existence of liberal Muslim groups which are mostly represented in NGO groups is stimulated by international agencies which supported their programs. The Ford Foundation and The Asia Foundation (and less visibly AusAID and a range of other foreign-government agencies) between them are responsible for most of Indonesia's booming NGO industry, including Islamic NGOs, and to a considerable extent setting their agendas. Most of the Muslim NGOs working at the grassroots level have a personal or ideological affiliation with Nahdatul Ulama (NU). Activists of Muhammadiyah and similar reformist backgrounds tend to get involved in a different type of efforts than the typical NGO: discussion groups and other forms of adult education, charitable work, and cooperatives. They tend to be less dependent on sponsoring by foreign agencies. ${ }^{16}$

Some influential Muslim NGOs take pains not to appear too closely associated with either NU or Muhammadiyah such as Rahima, which focuses on gender issues, organizes training for girls and young women mostly but not exclusively of a pesantren background, and attempts to develop an Islamist feminist discourse, critically engaging with established views and current teachings that place women in a subservient position. A more recent phenomenon, but not an NGO proper, is the Liberal Islam Network (JIL). The network started out as a mailing list and website, soon adding a radio program, relayed by local stations in a number of Indonesian cities, and a syndicated newspaper column. Its core members have deliberately sought a high profile in the media because they feel that Muslim intellectuals have too long been involved in arcane discussions and left the production of simple and accessible texts on Islam for large audiences to the Islamists. More than any other group, JIL sees the struggle against narrow and intolerant interpretations of Islam as its chief mission. Unsurprisingly, Islamists of various stripes soon identified JIL as one of their own chief enemies. ${ }^{17}$ It could be seen from the attacks and criticism of Muslim liberal's view in Islamist media, more particularly in Sabili.

The other advanced action of liberal Muslims in the post New Order era is the creation of the Islamic liberal magazine Syir'ah, which was fist published by the Desantara Institute ${ }^{18}$ in 2001 . This monthly magazine is supported by The Asia Foundation and concentrates on counter-discourses of narrow interpretations of Islam as raised in Islamist magazines. The issues which are raised in this magazine are almost similar with that raised 
by JIL. However the magazine appears to be "brave" and tried to be simple in presenting controversial issues such as gay and lesbian rights, Islamic communism, sexual encounters amongst santris, Islam and local superstition, and so forth. However, this magazine does not attract as many readers as its Islamist counterpart. ${ }^{19}$ The reason for this decline might be due to the way they present their views which seem to be vulgar and radical. Besides, the language used in this media seems to be abstract and sophisticated for common Muslims in Indonesia.

As for the Islamist groups and their media activities, although there have been many Islamist magazines none of them have seen the same success as Sabili. Besides Sabili, other prominent magazines include:

- Annida -This magazine was first published in 1991 under the company PT.Kimus Bina Tazkia. The magazine, which targets young Muslims, mostly contains Islamic short stories that stress Islamic ethics and identity. While the magazine encourages its readers to help Muslim Palestinians against Zionist Israel, unlike Sabili this magazine does not devote its energy to criticizing other religions.

- Ummi - The magazine was first published in 1989 and obtained SIUPP in 1998. Similar to Annida, the publication is owned by PT. Kimus Bina. The articles in "Ummi" which means "my mother", generally focus on issues of interest to Muslim mothers. In some instances, it does voice some criticism of Israel's repression of Muslim Palestinians. Unlike Sabili, however, the magazine is more focused on Muslim family issues rather than politics and opposition to Christians and Jews.

- Tarbawi - As evident by its name "tarbawi", or "educational", this magazine is linked to the Tarbiyah movement. Targeting Tarbiyah activists (although it is not explicitly stated), the magazine provides religious education and guidance for Muslim activists for living in the worldly life. The social activities of Partai Keadilan Sejahtera (PKS), the Islamic party which was established by the tarbiyah activists, are often promoted in this magazine.

- Saksi-This magazine focuses on national political issues with a strong emphasis on PKS political views. This magazine displays some similarities to Sabili in that it covers the struggle of Muslim leaders in implementing Islamic shari'ah in several regions, and promotes the implementation of Islamic law as the solution to Indonesia's economic, political and social problems. In certain editions, Saksi presents the face of American politics which is dominated by conservative Christians. 
The issues raised in such magazines would indicate that they are dominated by the ideology of the Tarbiyah movement. There are various indications of this. First, the issues and the arguments raised by these magazines are concomitant with the Tarbiyah ideology. Second, many writers and Muslim figures consulted with have a Tarbiyah/PKS affiliated background. Lastly, such magazines are closely linked with one another. For instance, the two magazines i.e. Annida and Ummi are owned by one company. Additionally, some editors of Tarbawi magazine namely Ahmad Zairofi and M. Lili Nur Aulia previously worked for Sabili.

As stated carlicr, one indication of the resurgence of Islamic radicalism in the post Soeharto era is the proliferation of Islamist discourses in the public sphere. These Islamic magazines have a significant readership base in Indonesia. Agus Muhammad noted that the circulation of Ummi for example is around 80,000 copies per-edition. ${ }^{20}$ Ideas presented by this magazine and those like it may hinder the creation of civil society and civic pluralism in Indonesia. Although the substantialist Muslims had more opportunities than Islamists in dominating the public sphere in the past, that appears not to be the case in the post New Order era, as can be seen from the rising popularity of Islamist magazines.

\section{Sabili and Islamism}

Sabili was first published one year after the 12 September 1984 Tanjung Priok incident. ${ }^{21}$ It emerged in the context where the expression of political Islam was suppressed by the Soeharto regime. In the New Order era, there were many policies of the government that suppressed the Muslims or contradicted Islamic values. ${ }^{22}$ The most contentious one is the application of Pancasila as the sole foundation (asas tunggal) for all political parties and mass organizations. The government's main motive was to safeguard Pancasila as the state's national ideology, and to continue to disseminate it amongst society. ${ }^{25}$ Many Muslim mass organizations objected to the government's idea for fear that adopting Pancasila as their sole basis could mean that Pancasila would replace Islam, or that Pancasila would be made equivalent to religion. ${ }^{24}$ In the name of safeguarding Pancasila, the regime arrested Muslim activists, preachers, and Muslim figures who rejected Pancasila. Moreover, many preachers were controlled and prohibited from preaching in mosques and even put in jail, accused of provoking Muslims to oppose the New Order government. ${ }^{25}$ The dissatisfaction of Muslims to the repressive government reached its climax in the bloody clashes between militant Muslims and the military in Tanjung Priok, North Jakarta in 1984. This incident left hundreds of Muslims dead or injured. ${ }^{26}$ 
Several years before the Tanjung Priok incident, a group of young Muslims tried to look for the ideal format of an Islamic movement. Zainal Muttaqin, a student of University of Indonesia (UI) and part of the first generation of Tarbiyah movement members at UI, with his colleagues established a study club called KTAI (Kelompok Telaah dan Amaliah Islami) [the Islamic Analysis and Conduct Group]. They used a new type of Islamic $d a^{3} w a h$ by basing their activities on what they believed to be a true and comprehensive understanding of Islam. ${ }^{27}$

In carrying out their da' wah activities, they found it necessary to find a medium through which they could provide a wider understanding of Islam and shape Muslim thinking. ${ }^{28}$ Practically speaking, their idea was mainly spurred by the fact that many Muslim activists coming from secular universities, notably the students of UI, could not access Islamic literature in their own language because most was written in Arabic. Furthermore, they sought to use the media initially to provide spiritual education through articles and translations. In materializing the idca, they published a bi-monthly magazine called "Sabili". ${ }^{29}$

The name of Sabili which means "my way" is inspired from one word in verse 108 of Surah Yusuf. ${ }^{30}$ The verse reflects their spirit to create an ideal $d a$ "wah movement. ${ }^{31}$ According to Rahmat Abdullah, the first general chairman of Sabili, the verse deals with several important points, most importantly the harakah or da'wah movement, which is neither a silent da' wah nor a da'wah activated by mass, but a kind of da' wah that revives the masses. ${ }^{32}$

The establishment of Sabili in the 1980's was risky considering the fact that the Soeharto regime, supported by the military was very repressive of any Islamic and leftist movements. Furthermore, for most of the New Order, the media appeared to be under the command of the government, controlled through the censorship process and increasingly through ownership. ${ }^{33}$ In such a context, it is easy to understand why there were almost no newspapers and magazines which explicitly raised criticism of the New Order regime. What is more, all newspapers and magazines were required to obtain a SIUPP from the Ministry of Information which was very difficult to get at that time since it went only to individuals or companies with close connections to the political establishment especially the Golkar Party. ${ }^{34}$ Nevertheless, Zainal Muttaqin and his colleagues published Sabili without a SIUPP. For Muttaqin, the publication of Sabili was partly a form of protest to the political system which did not accommodate the rights of people to express their ideas and inspirations. ${ }^{35}$

The first edition of Sabili was published under the institution of KTAI. The general chairman was Rahmat Abdullah ${ }^{36}$ while the editor in chief was 
by Zainal Muttaqin. The cover of the magazine was coloured with purple, illustrated with the word Allah in Arabic calligraphy on it without putting a date, month, year and address. The editorial introduction in the first edition states that the motivation for publishing Sabili at that time was the fact that there was no media that could present an 'authentic' and 'comprehensive' picture of Islam, educate Muslims with Godly (Rabbani) ideas and thought and guide them to the hansf way of life. ${ }^{37}$ It appeared that media at that time was dominated by 'secular' Muslim figures ${ }^{38}$ who rejected political Islam and it therefore might be assumed that Sabili was a response to such a situation. However, it should be noted that the first edition of Sabili became the last edition due to the lack of finance and human resources who could seriously handle the media. ${ }^{39}$ Besides, the general chairman Rahmat Abdullah was so busy in da'wah activities that he could not focus on developing the magazine. ${ }^{40}$

After disappearing for a few years, Sabili was published again in 1988 under the initiative of Zainal Muttaqin with the permission of Rahmat Abdullah. Muttaqin became the general chairman and editor in chief at the same time. In the introduction of the first edition, 5-20 Rabi'ul Awal 1409 $\mathrm{H}$, the editor in chief wrote that the return of Sabili was accompanied by better preparations. One of them was a more solid work ethic of the staff. This was reflected in the survival of the magazine, albeit the schedule of publication (i.e. twice a month) was sometimes broken. It began publishing regularly in the fourth year. As a result, the circulation of Sabili magazine experienced a significant increase from 2000 copies in the first publishing to 65,000 copies for the last edition in $1993 .{ }^{41}$ According to Muttaqin, the newly special format of the magazine in the second period (19881993) might have contributed to this increase.

The content of Sabili was divided into three parts: first, issues around the Muslim world (al-alam al-Islami). Second, issues related to the heritage of Islam such as tsaqafah Islamiyah (Islamic culture), tarikh (the history of Islam) and ibroh (lessons). The third was Indonesian issues. Amongst the issues covered, the Islamic world was the distinctive characteristic of this magazine in the later years of the New Order. According to Muttaqin, there was no Islamic media that intensively reported the oppression of Muslims in Palestine, Afghanistan, Chechnya, Kashmir, and Bosnia except Sabili. ${ }^{42}$ This might be what made it popular among Muslim activists during the New Order regime since by reading Sabili Muslims who were suppressed by the government could share the same feelings of their brothers in other parts of the world.

Sabili's popularity and appeal lay in its coverage of da'wah related issues; This symbiosis was managed by those who actively engaged in 
da'wah and understood both the area of da'wah and what the Muslims needed. In other words, Sabili indirectly participated in designing the da'wah strategy. ${ }^{43}$

However, Sabili faced a serious problem when it presented the letter of a reader in the $7^{\text {th }}$ edition of the fifth year of publication ( 20 November- 5 December 1992). The letter revealed the harassment and Christianization of a veiled Muslim woman by three missionaries. The reader gave details of how she was brought to a quite place in Rawamangun near IKIP Jakarta campus. In that place, she was forced with a knife to give up all of her jewellery and to say Christian words. Fortunately, she was able to escape. The letter was regarded by the Minister of Security L.B. Moerdani and the Commander-in-Chief of the Restoration of Security and Order Soedomo as something which could spark the masses and it was for this reason that the high court of Jakarta called in the editor in chief of Sabili for clarification. $^{44}$

The editor in chief Zainal Muttaqin decided to reject that call after receiving information from an acquaintance in the high court that this was only a strategy to arrest him since many Muslim activists who were called by the high court were put in jail with the allegation of opposing Pancasila as the state ideology. Although Sabili continued to be published for sometime after this, it was decided that after the $11^{\text {th }}$ edition (20 January -5 February, 1993) printing would cease due to the great risk the Islamic activists faced as targets of the regime. ${ }^{45}$

The collapse of the New Order regime in May 1998 and the reforms that followed paved the way for greater press freedoms in Indonesia. This resulted in the mushrooming of the media industry, particular Islamic magazines. In response to this, Sabili returned to publish in June 1998 under the institution of KTAI, the same institution they used in the Now Order. ${ }^{46}$ However, it was only stated in the first and the second edition. Since the third edition, it has been stated that the publication of Sabili is under company of P.T. Bina Media Sabili. ${ }^{47}$ It indicates that KTAI was transformed into a business company. Since Sabili became a company, it has become financially stronger than before. To establish a company, Muttaqin invited some Muslim businessmen to invest in Sabili. The ten investors of Sabili are as follows: Rahmat Ismail (26\%), Thoriq Basalamah (10\%), Abdul Muthalib (5\%), Lutfi Amir Tamimi (5\%), Aryono Madyanto $(5 \%)$, Zainal Muttaqin (10\%), Farid Prawiranegara (10\%), Djufri Djamaan $(10 \%)$ and Kemas Taufiq Mochtar $(9 \%){ }^{48}$ Rahmat Ismail, who has the highest investment, was appointed to be the main commissary, Abdul Muthalib as the general chairman, and Zainal Muttaqin as the editor in chief. ${ }^{49}$ Sabili obtained an SIUPP from the Ministry of Information on 30 
July $1998 .^{50}$ By having an SIUPP, Sabili was better able to compete in the open market. However, in an attempt to reach even greater heights in the market, Sabili staff held a work meeting on 10-11 July $1998 .{ }^{51}$ In the meeting, Rahmat Ismail stated his wish that Sabili magazine would one day be read by Muslim preachers in villages before they deliver their Friday sermon. The target audience would be the mosque youth, members of religious study groups in school (ROHIS), and members of Islamic social organizations, as well as professionals who wanted to return to Islam. The target age group would be readers aged between 16 and 40 years old, those who have graduated from senior high school and are middle income earners. ${ }^{52}$ According to Muttaqin, this decision was made in order to catch a niche market, and once the magazine was better established, it was envisaged, Sabili would focus on other markets. ${ }^{53}$

In the meeting, it was also decided that Sabili would be "the media for all," for any Muslim without consideration for their political affiliation, religious schooling, and organization. In this regard, Sabili was expected to be a uniting bridge for the various Muslim groups in Indonesia. According to Salman, the Director of Sabili, the media ideally should not affiliate or side with a certain political party since it would limit their market. Harian Abadi, the media of Masyumi Party, is a good example of this since because of its narrow focus it was not able to survive in the New Order era. $^{54}$

Furthermore, Sabili was intended to describe the universality and the completeness of Islam. Therefore, the policy of news of Sabili stems from four principles: ishlah (reform), ukhuwah (brotherhood), tasamuh (tolerance), and rahmah (mercy). Sabili, at the same time, is intended to be assertive in rejecting and fighting against what they perceive as errors (batil) and deviances. ${ }^{55}$

The return of Sabili was welcomed by Muslim figures who remembered it from before. Their satisfaction was displayed in letters to the editor. For example, Hussein Umar, a member of the house of representative, expressed his hope that Sabilicould become the main representative for Muslims in facing the Western media that discriminates Islam. ${ }^{56} \mathrm{Mu}-$ tamminul Ula, the former chairman of PB-PII, also provided positive comments about Sabili, expressing his belief that Sabili could provide the best for Muslims, by writing rational and true news, and voicing the aspirations of Muslims. ${ }^{57}$ Amin Rais, the locomotive of reformation in Indonesia, hoped that Sabili could become a professional magazine which would work for the betterment of the ummah, analytical and clever at presenting information, and brave in voicing the truth whatever the risk. ${ }^{58}$ Similarly, Arif Rahman, an expert in education, hoped that Sabili could cover issues of 
pertinence to Muslims. ${ }^{59}$ A. Mansyur Surnegara, a historian, suggested that Sabili should be the voice of the weak and oppressed people. ${ }^{60}$

Presented with the same format and logo as in the previous publication, the circulation of Sabili has increased gradually from over the years to more than 100,000 copies in 2000. For Muttaqin, this fact shows that the presence of Sabili was not only welcomed by certain Muslim groups but also by Indonesian Muslims at large. ${ }^{61}$

However, critical comments were also directed at the magazine, revealing its wcaknesses. Deliar Noer, the general chairman of the Islamic Ummah Party (PUI) for instance, criticized the news about the joining of PUl with ten parties in forming a forum of communication of total proreformation parties while in fact it did not. He stated that Sabili did not check the truth of such news. ${ }^{62}$ Other criticism was made by AMJ Putra, the editor in chief of 'Link' magazine of UI. After reading four Sabili magazines, he concluded that Sabili is emotional, inflammatory and condemning, neither fair nor clever in its opinion, lacking of a journalistic touch, and presenting an Islamic understanding which is hard and 'strange' for common people. ${ }^{63}$ Atmakusumah Astraatmaja, the chair of the Press Council (Dewan Pcrs) even labelled Sabili as pamphlet media since its writing stylc and report presentation are not in line with professional press and journalistic standards. ${ }^{64}$

In spite of the weaknesses of Sabili, it could not be denied that Sabili was a pioneer of Islamist media in the reformation era. Its return in June 1998 was followed by the proliferation of Islamist magazines such as Ummi, Annida, Saksi, Tarbawi, Al Izzah, Darul Islam, Salafy, Pcrcikan Iman, Hayatul Iman, Gema Islam, El-Fata, and Islamia. These magazines emerged and obtained an SIUPP during the years 1998-2004. It might be assumed that there will emerge other Islamist magazines in the years to come. The cmergence of such magazines may be motivated by the popularity of Sabili in the public spherc.

\section{Vision and Mission}

The vision of Sabili is to become a professional and innovative magazine for the da' wah movement by presenting an accurate and comprehensive picture of Islam, to tighten ukhuwah (Muslim brotherhood), and to become a hub for those in the field of da'wah who have potential in journalism. ${ }^{65}$ The mission of Sabili is as follows: ${ }^{66}$

1) To carry out comprehensive, authentic, undeviating, continuous, educating, and empowered da'wah.

2) To present Islamic thought that is comprehensive and covers all aspects of life (syamilah mutakamilah). 
3) To become a medium that protects Muslims from the 'war of thought' (ghazwul fikri) and tightens the brotherhood of Muslims.

4) To place itself as the sustainer of the da'wah movement.

5) To become a means of journalistic development for those involved in da'wah.

Given the mission and vision of Sabili above, it appears that Sabili holds views which are generally voiced by Islamists namely that authentic Islam is drawn from the main sources of Islam, that is, the Qur'an and the Hadith, as well as the example of the salaf as-saaleh (the pious predecessors, reference to the earliest generations of Muslims). For Islamists, any thought and interpretation which is not in accord with both religious texts would be regarded as deviation and thus would not be accepted. According to Roy, the Islamists generally adopt salafi theology: they demand a return to the Qur'an, the Sunnah, and the shari'ah and reject tradition, philosophy and Islamic mysticism (tasawwuf). ${ }^{67}$ In this respect, critical Islamic heritage is not respected by Islamists. This view has been represented by many writings in Sabili. There is less discussion dealing with philosophy and tasawwuf. However, if they are available, the writers are more likely to suggest the readers to be alert in dealing and practicing them since some practices of tasawwuf are contradictory with the Qur'an. ${ }^{68}$ Therefore, it is not surprising that Sabili in its editions often criticizes certain Islamic schools or Liberal Islamic thought, which they see have as being deviant.

The second element that Sabili stresses in its vision and mission is the comprehensiveness of Islam. In this regards, Sabili sees Islam as a complete and universal system (käfah) and accordingly, Islam is not seen as merely religion, but as a political ideology that guides all aspects of social life (politics, law, economy, social justice, foreign policy and so forth). Building on this basic view, Sabili demands that the Islamic state, formal shari' $a h$ and economic shari' $a h$ should be applied as the solution for problems faced by Indonesia. As a consequence of this view, Sabili criticizes any concepts coming from the West such as capitalism, secularism, materialism, socialism, pluralism, gender, and so on.

The formulation of the vision and mission of Sabili could not be separated from the socio-political conditions of Indonesia in the New Order era. Sabili emerged in the political context where political Islam was suppressed by the New Order regime while cultural Islam as presented by 'secular Muslim intellectuals' was supported. The founder of Sabili, Zainal Muttaqin, asserted that 'secular' Muslim intellectuals such as Nurcholish Madjid and Abdurrahman Wahid dominated the media, especially Tempo 
and Kompas in the 1970's and 1980's, as if there were no other Islamic perspectives except what they wrote. For him, Islamic views presented by such Muslim figures have deviated from the true Islam and there opinions tend to secularize Indonesian Muslims. ${ }^{69}$ Therefore, the emergence of Sabilf in the 1980s is partly a response to such a situation aiming to present Islamic teachings which they perceived as being more authentic and comprehensive.

\section{Themes}

The themes covered in Sabili in the post New Order era are much different with those covered during the New Order days. One of the reasons Sabili was able to continue its operations without any restrictions from the government during the New Order era is that it focused on international issues namely alam Islami (the Muslim world), education and da'wah while national politics received scant attention. In the post-New Order era, however, Indonesian contemporary politics has become the central theme for Sabili although the coverage of major international issues is not neglected. ${ }^{70}$

The stories contained in each edition of Sabili is generally divided amongst three main topics: national issues, international issues and Islamic heritage. This format follows that which was formulated by Zainal Muttaqin during the New Order days. However, there is a clear difference; as mentioned above national issues have certainly dominated the magazine in the postNew Order days.

The magazine's critical and provocative style is not only evident in the headlines and titles, but also in the way the editors present the coverage. The words which are used appear to be clear, unsophisticated, sharp, and somewhat biased. That is to say that sometimes Sabili secms to present the full criticisms and opinions of the Islamists but neglects the voiccs of the other side. At first glance, Sabili seems to cover-both-sides, however, if one analyzes the coverage, it will certainly appear unfair and unbalanced. The example of this could be seen in the editorial of the Counter Legal Draft of the Compilation of Islamic Law (CLD-KHI) issue. In its coverage of this issue, Sabili covers many negative reactions from MUI, ulama, and Islamist groups against the draft while few clarifications and opinions from the liberal Muslims are included.

\section{Editors}

The editorial staff at Sabili is composed of mainly young Muslims who have a great da'wah spirit. The educational background of the editors varies (See Table 1 below). Most of them, including the former editor in 
chief, come from secular universities such as University of Indonesia, UGM, IPB, and Trisakti University, while few come from Islamic colleges such as the Islamic and $\Lambda$ rabic studies institute (LIPIA). This is due to the fact that Islamist students generally come from secular universities. In terms of political affiliation, the editors vote for Islamic parties i.e. PPP, PAN, PBB, and PKS. However, according to Salman, most of them vote for PKS. ${ }^{71}$ Before working in Sabili, many of them have engaged in da'wah activities in Islamist organizations or Islamic study clubs such as the Tarbiyah movement, PII, PERSIS, and Islamic media (Hidayatullah, Damasena, and Salam). It could be said that they were experienced in da'wah activities before working in Sabili. ${ }^{72}$

Table 1:

Educational and Organizational Backgrounds of the Editors

\begin{tabular}{|l|l|l|l|}
\hline No. & \multicolumn{1}{|c|}{ Editor } & \multicolumn{1}{|c|}{ Education } & \multicolumn{1}{|c|}{ Islamist Organization } \\
\hline 1 & Zainal Muttaqin & $\begin{array}{l}\text { University of Indonesia } \\
\text { (UI), LIPIA (not finished) }\end{array}$ & $\begin{array}{l}\text { Pelajar Islam Indonesia (PII), } \\
\text { Tarbiyah Movement }\end{array}$ \\
\hline 2 & M.U. Salman & UNISBA & $\begin{array}{l}\text { PII, Lcmbaga Da'wah } \\
\text { Kampus (LDK) }\end{array}$ \\
\hline 3 & Rivai I Iutapea & $\begin{array}{l}\text { Gajah Mada University } \\
\text { (UGM) }\end{array}$ & LDK \\
\hline 4 & Ilerri Nurdi & Pesantren Hidayatullah & Pcsantren Hidayatullah \\
\hline 5 & Nurcholis Ridwan & LIPIA & PERSIS Bangil, LIPIA \\
\hline 6 & Hepi Andi & LIPIA & LIPIA \\
\hline
\end{tabular}

The background of editors seems to have contributed to their radical views on Islam. Nurcholis Ridwan, for instance graduated from the PERSIS Pesantren in Bangil, East Java. After completing his senior high school, he taught Islamic studies for two years in Darul Istiqamah in Makassar. Darul Istiqamah is perceived by many as a hard line pesantren which often receives financial aid from Islamic foundations in Saudi Arabia. He then continued his graduate studies in LIPIA in Jakarta. LIPIA, which is fully funded by the Saudi Government, has been maintaining Wahhabi Salafism in teaching. ${ }^{74}$ Most of the lecturers of this college graduated from the Middle East. While studying in LIPIA, Ridwan participated in a selection test for Sabili in 2001 and passed..$^{75}$ 
Salman studied in the journalistic department of the Faculty of Communications at UNISBA. He actively engaged in campus da'wah activities during his undergraduate studies. Furthermore, he was able to experience working as a journalist in harmonis magazine, Salam Islamic magazine and the Indonesian Journalist Union (PWI) in Bandung. In 1998, he was invited by his senior friend Zainal Muttaqin to be editor in Sabili. ${ }^{76}$ Since 2001, he has bcen the editor in chief replacing Muttaqin.

Rivai Hutapca graduated from the Faculty of Law at the University of Gajah Mada Yogyakarta (1996). There he was involved in Campus Dakwah Movement (LDK) activities during his studies. After he graduated, he worked as a Journalist in Darmasena Islamic Magazine, a magazine which belongs to the Indonesian military (ABRD). Through this, he got acquainted with Zainal Muttaqin who was also a journalist. In 1998, He was invited by Muttaqin to help him in developing Sabili. In Sabili, he has been working as a reporter and editor. Recently he became the coordinator of reporters. ${ }^{77}$

Herry Nurdi stands out as being quite different to all of the other editors at Sabili. Although he only graduated from senior high school, life experience had taught him a lot and was blessed to have been heavily involved in the media for some time. He had written several articles in Jakarta Post and Republika before coming to Sabili in $1999 .^{78}$

\section{Writers}

The writers who contribute their articles in Sabili are often Islamist intellectuals and Muslim figures. Their views are in line with Sabili's, which seeks to promote the implementation of shari' $a$ h in Indonesia. Many writers belong to certain Islamist groups and Islamist parties in Indonesia. Among the writers and Muslim figures consulted by Sabili are:

- Dr. Daud Rasyid, who is currently a lecturer of ININ Sunan Gunung Jati Bandung. He is a well-known Muslim intellectual who promotes the implementation of shari'ah and has been a consistent critic of liberal Muslims. In the 1990s, he actively wrote articles in Mcdia Dakwah against the renewal ideas of Nurcholish Madjid. ${ }^{79}$ In the years following the fall of Soeharto, he has been a regular writer for Sabili.

- Al Habib Muhammad Rizieq Syihab is the leader of the Islamic Defenders Front (Front Pembela Islam, or FPI). FPI was founded by habaib (Indonesians of Arab descent), Islamic teachers and scholars on the $53^{\text {rd }}$ Indonesian Independence Day, August 171998 in Jakarta. The establishment of this organization was motivated by the spirit to cradicate immorality (ma'siyat), and in striving to do so FPI has at- 
tacked a number of bars, karaoke clubs, and pubs in Jakarta. The distinctive feature of FPI, which distinguishes itself from other Islamist groups, is its destructive actions in materializing its aims. The major aim of FPI was to promote Islamic shari'ah in the corridor of Indonesian nation. ${ }^{80}$

- Irfan S. Awwas is the Chairman of the Executive Board of Majelis Mujahidin Indonesia (MMI) which was launched in Yogyakarta in August 2000. The head (amir) of the organization is Abu Bakar Ba'asyir, one of the founders of the Ngruki Pesantren in Surakarta. The main agenda of MMI is to implement shari'ah in Indonesia. In contrast to FPI which has at times resorted to violence in achieving its aims, MMI has chosen the political approach to promote its agenda. For example, MMI members advocate the implementation of shari'ah by encouraging discussion through public debates, the mass media, through writings on the internet and by publishing books. ${ }^{81}$

- Adian Husaini, who was the Gencral Secretary of Komite Indonesia untuk Solidaritas Dunia Islam [KISDI], ${ }^{82}$ or the Indonesian Committee for solidarity with the Islamic world, is one of Indonesia's most prolific writers on the subject of the implementation of shari'ah in Indonesia. The other issues he often raises in his writings and seminars are criticism of US foreign policy and liberal Muslim ideas. He is now taking his $\mathrm{PhD}$ in the University of Islamic Thought and Civilization (ISTAC) Malaysia. ${ }^{83}$

- Hartono Ahmad Jaiz has since 1998 been the Chairman of lajnah ilmiyyah (rescarch division) of the Institute of Islamic Research and Studies (Lembaga Penelitian dan Pengkajian Islam-LPPI), an Islamist organization. Jaiz is a well-known writer who often criticizes 'deviant' Islamic groups and liberal Muslims in Indonesia. Among the books he has written include: "Deviant Islamic schools and thinking in Indonesia" (2000), "The Danger of The Jaringan Islam Liberal (JIL) and Fikih Lintas Agama (FLA)" (2002), "Therc is Apostasy (Pemurtadan) in IAIN" (2005).

- Ismail Yusanto is the Spokesperson for Hizbut Tahrir Indonesia (HTI). Hizbut Tahrir is an international Islamic group which was founded by Taqiyuddin Al-Nabhani in carly 1952 in al-Quds, Palestine. HT entered Indonesia in the 1980s. The main goal of this organization is to establish Khilafah Islamiyah since nationalism is seen as fanaticism (ashabiyyah) and contradictory with the objectives of Islam. ${ }^{84}$ In Indonesia, one of the most well-known slogans used by this organization is, "Save Indonesia with shari'ah!" ITI's defining characteristic is its noncooperative attitude with the government. 
- Hussein Umar is the General Secretary of Dewan Dakwah Islam Indonesia (DDII). DDII is a Jakarta-based national organization, founded in 1967. It's membership is dominated by religious teachers and officials (ulama and zuama). DDII sends Islamic preachers ( $\left.d a^{\prime} t\right)$ to remote parts of Indonesia, helps to build mosques, and publishes $\mathrm{Me}$ dia $D a$ 'wah, a magazine notorious for its attacks on liberal Muslims and the Christians during the New Order period. It is among the most extreme or militant groups tolerated by the government. ${ }^{85}$

- Anwar Hasan is the General Secretary of Komite Persiapan Penerapan Syariat Islam (KPPSI), or the Committee for the Preparation of the Implementation of Shari'ah. KPPSI was established during the first South Sulawesi Muslim congress in October 2001. This committec aims to implement shari'ah in South Sulawesi through regional parliament. KPPSI's struggle has received significant support from the legislative body, regional government, Muslim figures and community in South Sulawesi. ${ }^{86}$

- Abu Deedat Shihabuddin is the Chairman of Forum Anti Kristenisasi dan Pemurtadan (FAKTA), or Anti-Christianization and $A$ postacy Forum. As implied by its name, FAKTA is an institution which focuses on researching and reporting activities of Christianization in Indonesia. There is a special section in Sabili - Bimbingan Tauhid - which is especially for this institution to discuss and denounce Christian doctrines in order to warn Muslims from the danger of any kind of Christianization in Indonesia.

Given the backgromd of some the writers, it could be said that Sabili is a platform for the Islamists to express their vicws and ideas. However, it should be noted that not all writers or Muslim figures presented in Sabili could be described as Islamist, but are rather consulted because of their knowledge of a particular issue. For instance, Azyumardi Azra, a leading moderate Muslim intellectual, once wrote an article on Islam and political issues in Sabili. He is also often interviewed by Sabiliconcerning national political issues. Similarly, national political observers such as Bahtiar Effendi, Eep Saefullah Fatah, and Imam Prasojo are also sometimes consulted. In criticizing American politics, Sabili sometimes consults with the Indonesian Board of Intelligence and intelligence obscrvers. Since political issues and da'wah are dominant in Sabili, the figures presented are dominated by political observers, activists, politicians, and Musiim figures of da'wah. In terms of Islamic discourse, moderate personalities such as Quraish Shihab, Ali Yafie, and Komaruddin Hidayat are hardly interviewed or consulted, and this is certainly because their religious views are not in line with Sabili's views. 


\section{Readers}

In the New Order era, Sabili's readership was limited to mosque youth, da'wah activists in Islamic organizations, and members of religious study clubs in campuses and schools. The magazine was only circulated among such readers and it was not widely available in the market place. However, after its return in 1998, it has been sold and circulated. ${ }^{87}$ The results of the AC Nielsen ${ }^{88}$ survey below illustrate the cross-segment of Sabili readership in 2002-2003:

Table 2:

The readership survey of AC Nielsen 2002-2003

a. Sex of the readers:

- Men

- Women

b. Ages:

- 15 - 34 years

- $\quad 35-39$ ycars

- $39+$ ycars

c. Economic Status:

- Class $\triangle$ and B

- Class C1

- Class C2

- Class DE

d. Profession:

- Official Employee/Professional:

- Student

- Houscwifc

- Low Employee

- Retired

- Entrepreneur

e. Education Level:

- Senior High Scholl : $\quad(30 \%)$

- Junior High School : : (25\%)

- College/Academy : (34\%)

f. Regions of Circulation:

- Jakarta and BOTAB_EK ${ }^{89} \quad: \quad(50 \%)$

- West Java : $(11 \%)$

- Central Java $\quad: \quad(7 \%)$

- Last Java : $(6 \%)$

- Sumatera $\quad: \quad(16 \%)$

- Kalimantan : $(4 \%)$

- Sulawesi $\quad: \quad(4 \%)$

- Bali, Southeast Nusa : (1\%)

- Maluku, Irian Jaya (Papua) : (1\%)

- Abroad and others : (1\%) 
The survey shows that while Sabili is read by various groups of people in terms of sex, age, economic status, profession, education and so on, Sabili is more popular among young Muslim professionals and students. Their most common Sabili reader is between 15 to 34 years old, well off and has at least a senior high school or university education. By contrast, the lower income groups aged 35 and above are less likely to read Sabili. Furthermore, the readers mostly come from big cities and areas such as Jakarta, Bogor, Tangerang, Bekasi (50\% of readers) and Sumatra (16\%).

It is also evident from the survey that the target market of Sabili has been expanded from students and Muslim activists to professionals. Nevertheless, the survey does not reveal the affiliations (Islamic organization and Islamic school) of the readers. It might, however, be assumed that the readers of Sabili are indeed affiliated in some way to Islamist organizations or religious study clubs since the background of Sabili's readers in terms of age, occupation, and education are in line with that of Islamist groups in Indonesia. Islamist groups such as the Tarbiyah Movement or Hizbut Tahrir for example are followed by urban young Muslims with a higher level of education and income. ${ }^{90}$ This is also supported by the fact that the percentage of Sabili readers in Java and out of Java is quite low. In East Java for example, readership was only $6 \%$ of the total and this is due to the fact that this region is a Nahdatul Ulama (NU) dominated area. For Central Java, noted Muttaqin, Sabili is more popular in ex-Masyumi or santri based coastal regions (daerah pantura) such as Semarang, Tegal, Dcmak, and Kudus.

\section{The Popularity of Sabili}

The success of print media depends on circulation and advertisement. In the Indonesian context, a magazine would survive if its circulation could reach around 30,000 copies for each edition. ${ }^{91}$ Although Syir'ah magazine sells only around 5,000 to 10,000 copies of each edition it is financially kept afloat through support from foreign foundations. Different to other existing magazines, Sabili mainly depends on its sales while advertisement only fill about 10 to $20 \%$ of its pages. In 1993, Sabili's circulation reached around 60,000 copies per-edition. In the post-New Order era, Sabili has been selling around 70,000 to 80,000 copies on a constant basis. The magazine experienced a spike in sales in 1999 to 2000 during the religious conflict in Ambon. According to Uki, the head of circulation and distribution, Sabili's circulation was more than 100,000 copies per edition at that time. More than 150,000 copies of Sabili's special edition Sejarah Emas Muslim Indonesia (The Golden History of Indonesian Muslim) was circulated in 2003. This edition was particularly popular among the pesantren 
community since they found it provided a considerably refreshing perspective on the history of Indonesian Muslim heroes as compared to other literature they read in school. Many commented that they would be use the Sabili special edition as a source of reference in history lessons in their pesantrens. ${ }^{92}$ The survey carried out by AC Nielsen gives us a better idea of the readership numbers and how Sabili stacks up against the rest (See Tables 3 and 4 below).

Table 3:

The Readership Survey of leading magazines 2000-2001

Greater Jakarta, Age 15+, No. of Readers ('000)

1. Gadis : 441

2. Sabili : 436

3. Femina : 390390

4. Kartini : 3360

5. Aneka :359

6. Misteri 324

7. Intisari 291

8. Bobo 277

9. Gatra 261

10. Liga Italia 259

Table 4:

The Readership Survey of leading magazines 2001-2002

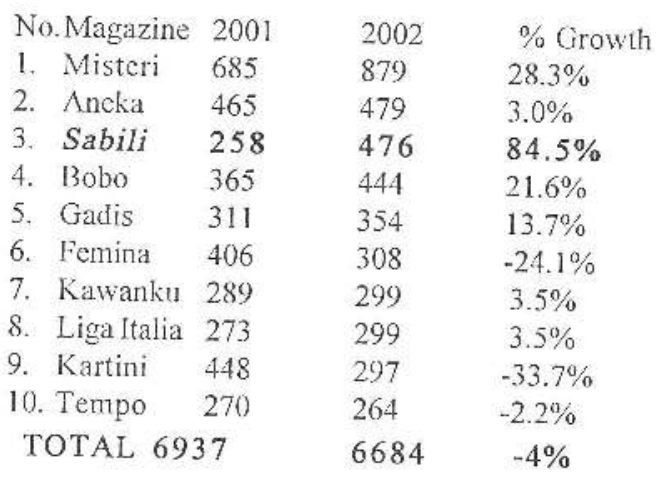


The first survey shows the readership numbers of the ten leading magazines in Indonesia during 2000-2001. The magazine with the highest readership is Gadis with 441,000 readers. Sabili is ranked second with 436,000 readers. It is interesting to note that Sabili is the only Islamic magazine presented in the list, coming in ahead of such leading magazines as Femina, Kartini, Gatra and Tempo.

The second survey shows the growth of readership of the ten leading magazines from 2001 to 2002. As can be seen from the table, Misteri is ranked in the first position with 689,000 readers in 2001 and 879,000 readers in 2002, representing a growth in readership of just under $30 \%$. Sabili, which was previously ranked second (in 2000-2001), fell to third position with 258,000 readers in 2001 and 476.000 in 2002 . However, In terms of the growth of readership, Sabili experienced an $84.5 \%$ growth in sales.

How can one explain the success of Sabili? The success of Sabili might be generated by the reforms it instituted and the content of the magazine itself. $\Lambda$ fter being repressed by the New Order regime, Muslims sought to find Islamic media which voiced their aspirations and promoted their Islamic identity. Sabili certainly meets these criteria. Moreover, the provocative issues contained in Sabili attract many Muslims to read it. The issue of shari'ah, criticism of the West, reports on the Christianization movement, and critics of the government are among the more popular issues presented by Sabili on a regular basis. According to the coordinator of reporters Rivai Hutapea, the fresh perspective taken by the magazine also contributes to its success. He exemplified this by referring to the religious conflict in Ambon in 1999 and 2000. While many within the media community were reluctant to report the religious conflict in $\Lambda$ mbon, Sabili acted differently by reporting on the developments from day to day in detail by advocating Muslims as the victims of the Christian groups. The result was increased readership of more than 100,000 copies during this period. ${ }^{93}$

Apart from the themes of the magazine and perspective taken by the reporters, the management and strategy should also be taken into account in attempting to determine the reasons for Sabili's success. Sabili has developed considerably in terms of quality over the years as a response to the suggestions and the tastes of the readers. The result can be seen in the improvement of the quality of the pages, colour and themes covered. Although the improvements have affected a price rise of the magazine, it has by no means meant significant drop in sales. The circulation of Sabili has remained stable at around 80,000 to 100,000 copies per edition. The other feature of this magazine lies in the pricing policy which - different to many other magazines - does not differentiate between Java Island and non Java. Most magazines charge an extra one thousand rupiahs for sales 
outside of Java. ${ }^{94}$ What's more, the distributors directly deliver the magazines to the agents of certain cities in Java in order to tighten the relationship the magazine has with the agents. The agents and distributors often discuss the magazine in an attempt to pin point areas in which it might be improved. ${ }^{95}$

\section{Islamist Views in Sabili}

This section aims to discuss and analyze the views propagated by Sabiliviews which can be generally categorized as Islamist - from 1998 to 2004. This can be done by examining the various themes of the magazine such as Sekitar Kita (Around Us), Ibroh (Lesson), Telaah Utama (Main Coverage), Telaah Khusus (Special Coverage), Indoncsia Kita (Our Indonesia), Kolom (Column), Tarqiyyah (Religious Advice), Alam Islami (Islamic World), Interview and Bimbingan Tauhid (Taubid Guidance). It is worth noting that this magazine is dominated by news of a political nature covering issues both in Indonesia and abroad from an Islamic perspective. As an Islamic magazine, one therefore often finds Islamic arguments within political coverage. The views and arguments that will be presented and analyzed in this section are those which are regularly presented in this magazine from one edition to another.

There are three primary themes that dominate Sabili articles, namely a shari'ah orientation, criticism of Christians and Jews, and condemnation of America. These three themes have coloured the articles of Sabili since 1998.

\section{Shari'ah}

If we look at various articles and reports in Sabili, it is evident that the writers and editors of the magazine are of the opinion that Islam is the one and only solution for humans in this world since God has provided a comprehensive guide for all mankind in the form of the Qur'an and Hadith. They generally insist that shari'ah should be followed and implemented as commanded in the religious texts since God's law abrogates human law. Due to its idealization of shari'ah, Sabili calls on its readers to support the implementation of shari'ah. Furthermore, by relying on the Qur' an and the Hadith as the standard of truth, Sabili has a tendency to criticize Muslim ideas and practices which appear to contradict the shari'ah. In line with the general vicws of other Islamist groups, Sabili identifics shari'ah as Islamic law derived from rules stipulated in the Qur'an and the Sunnah. Sabili's Islamist tendencies are evident from the views which are regularly reinforced by the magazine through the articles presented. These views include: 


\section{a) Islamic Law as the Solution}

In Sabili, it is often emphasized that Islam - through shari'ah - should play a significant role in contemporary Muslim life. Daud Rasyid, for example, argues that shari'ah is the most just law since it was revealed by God. Rasyid further points out that past experience with Indonesia's legal system has shown that it has brought nothing less than brutality, a lack of justice, and corruption. All of this, he says, has left Muslims with a desire to see shari' ah implemented throughout Indonesia. ${ }^{96}$ This opinion is shared by Agung Pribadi, who suggests that the failure of communism and capitalism in the world should pave the way for Islamic law to be introduced in Indonesia. This for him is fair because Islam is the majority religion in Indonesia, and he assures non-Muslims that they do not need to worry because shari'ah protects their rights accordingly. ${ }^{97}$

In backing their claims and the promotion of shari'ah, the writers sometimes refer to scientific researches and surveys. Topo Santoso, for example, argues that the implementation of Islamic criminal law in Saudi Arabia minimized the frequency of crime. He refers to Freda $\Lambda$ dler, the professor of criminology in the USA, who includes Saudi Arabia as one of the top ten countries with the lowest crime rates in the world. This opinion is also shared by Sam Souryal who stated that during the past ten years, the crime rate in Saudi Arabia is lower than Muslim countries which do not apply Islamic law. ${ }^{98}$ Similar arguments were maintained by Habibullah in the ibroh section of Sabili. He speculated that the increase in crime in Indonesia is mainly due to the use of secular law and the only solution to this problem is the implementation of shari'ah for it creates safety and establishes justice in society. II supported his argument by referring to the International criminology census in 1986 stating that the crime rate of a day in Canada equals 12 years in Saudi Arabia. ${ }^{99}$

It is interesting to note that in attempting to show the effectiveness of shari'ah in minimizing crime, the writers only took Saudi Arabia as a model while they overlooked other Islamic countries which also apply shari'ah to some degree, such as Pakistan, Iran, $\Lambda$ fghanistan, Sudan and Malaysia. What's more, there is a strong tendency to view the urgency of implementing shari'ah in terms of its positive impact on crime rather than its overall impact on public good. In this light it should be noted that according to Freedom House, Saudi Arabia is ranked amongst the worst countries in the world in terms of the protection of civil rights, illiteracy, and participation of women in the public sphere. ${ }^{100}$ This fact should be answered by Islamists who always refer to Saudi Arabia as the ideal country when it comes to the implementation of shari'ah. 
In attempting to implement shari'ah in Indonesia, two discourses have been broached by Sabili. The first is the establishment of an Islamic state (daulah Islamiyyah) in order to pave a formal way for Indonesian Muslims to implement shari'ah. The second is a return to the Jakarta Charter (Piagam Jakarta) by the insertion of seven words (i.c. "... with the obligation of the adherents of Islam to carry out shari'ah") in the constitution. However, as can be observed in the magazine's articles, the later discourse is more dominant than the former. Only a few articles stress the idea of the creation of an Islamic state in Indonesia.

The writers who favour the idea of an Islamic state argue that there is no alternative way to fulfil Muslim aspirations in Indonesia except by making Indonesia an Islamic state. By establishing an Islamic state, they assert, not only will old national problems be solved, but also the challenges of future can be anticipated, and it would mark the beginning of a new state and nation (ummah) in the world. ${ }^{101}$

According to Salman, there have not been any serious and systematic efforts made by Muslims to create an Islamic state in Indonesia for two reasons. First, the lack of a proper understanding of Islam within society, and second, a residual fear of an Islamic rebellion as initiated in the past by Muslim figures like Kartosuwiryo and Daud Beureuh. The impression that emerges now is that if Muslims seize power to establish an Islamic state, discrimination and oppression towards the non-Muslim minority will occur. For Salman, this is an erroneous perception. Throughout Islamic history we can see numerous examples of how non-Muslim communities living under Islamic law have been treated justly, such as the Jews and Christians of Madinaln during the time of the Prophet; all people were treated equally before the law regardless of their religion. ${ }^{102}$

The struggle for the implementation of shari'ah constitutionally is a prevalent issue in Sabili. As an example, issues on the insertion of the Jakarta Charter were raised in 1999, 2000 and 2002 in which the discourse on the amendment of the constitution became the agenda of discussion in the House of Representatives. Similar to previous arguments for an Islamic state, the writers contend that the revival of the Jakarta charter is a possible avenue for upholding Islamic law in Indonesia. ${ }^{163}$ Salman believes that essentially the notion of amending the 1945 constitution (by inserting the above-mentioned seven words) should be seen as the solution to solving the problems of this country. While many solutions in terms of the economy, politics, and socicty have bcen offered by experts, he stressed, none have succeeded completely in solving Indonesia's problems. Therefore, he says, "Why not try an Islamic solution?... as Muslims we absolutely believe that Islam is the solution." 
In a Sabili report, K.H. Firdaus points out that after the removal of the Jakarta Charter, disasters struck the country. In other words, if Islamic Law was implemented at least for Muslims, the situation of this country would be more peaceful and prosperous. ${ }^{105}$ Similarly, Zainal Muttaqin believes that the inclusion of the seven words would promote justice because one of the objectives of shari'ah is to create justice. He further claims that it would have numerous positive impacts on society. Most importantly, first, shari'ah will become a moral guide for Muslims and particularly the government, and second, shari'ah will force Muslim officials to uphold justice. This, he argues, will resolve what he views to be the country's biggest issue, that is, the degradation of morality of the politic elite. ${ }^{106}$

In establishing their arguments for the reinstatement of the Jakarta Charter, Sabili writers not only refer to Muslim activists and intellectuals but also to the experts of politics and law as well as political observers who favour the reformation of the 1945 Constitution. Harun al-Rasyid and Moch. Machfudz give five reasons as to why the 1945 Constitution should be changed. The first reason given is that the 1945 Constitution was only meant to be a temporary constitution, and it should thus be changed as Soekarno once declared. Second, based on the historical experience of Indonesia under the regime of Soekarno and Soeharto, the 1945 constitution has never created real democracy but rather a form of authoritarianism. Third, the 1945 Constitution contains rules which give the leaders too much power. Four, the Constitution gives too much authority to the president making it casier to be corrupt. As Mahfudz pointed out, "Socharto made so many rules for his business because he had the authority." Finally, the 1945 constitution is too honest to the character of man, whereas it should limit the power and authority of those in power when they abuse it. ${ }^{107}$ Although Rasyid and Mahfudz do not provide an Islamic perspective in showing the weaknesses of the 1945 Constitution, their critical arguments are imbued with an Islamist perspective in that they direct the readers to the idea of an Islamic constitution (the Jakarta Charter) as an alternative to the constitution.

Using a historical approach, the Sabili writers also argue that Islamic law is plausible to be implemented in Indonesia since it was the first law widely applied by Islamic kingdoms in the area in the past, and those kingdoms that lived by Islamic law experienced peace and prosperity. However, since the coming of the Dutch colonialists with their Christian mission, the role of Islamic law was eliminated from society. ${ }^{108}$

Apart from the historical experience of Indonesia, some writers refer to Madinah as the model for the Indonesian Constitution. There are two 
reasons why the reformation of the constitution should draw on Madinah as an example. First, Islam is the religion of a majority of Indonesian citizens and this situation resembles that of the society in Madinah in the Prophet's days. Second, Islamic values were able to bring justice to the various components of the society without discrimination in terms of religion, blood, or tribe. It was successfully implemented by the Prophet and the Caliphs when ruling the city. ${ }^{109}$ It is noteworthy that the reference to Madinah as a model society is not only held by Islamists but also progressive Muslims. Nurcholish Madjid, for example, regards Madinah as masyarakat madani, a term which for him is equivalent to the Western concept of 'civil society'. He emphasizes that in Madinah, social contracts between the citizens of different tribes and religions were honoured and this is typical of modern society. ${ }^{110}$ He equated the Pancasila with the Madinah Charter due to its accommodation of all religions in Indonesia. This indicates that there is a huge gap in the way in which Islamists and progressive Muslims viewing the Medinan society.

From the description above, it is evident that Sabili's argument for the implementation of shari'ah in Indonesia is based mainly on four factors namcly theological, demographic, historical, and socio-political. The first factor emphasizes the fact that Islam is a religion which offers guidance and solutions to of life's difficulties (economic, socio-cultural, political, and so forth). In this respect, shari'ah is seen as obligatory for Muslims to apply. The sccond factor points to the fact that the majority of Indonesians are Muslims. Adherents of Islam constitute 87 percent of the country's population. ${ }^{11}$ In Sabili, this fact alone should become socio-cultural and political legitimacy for the formal implementation of shari'ah. The third factor refers to the experience of Madinah in the era of the Prophet in implementing Islamic law, as well as the experiences of the Islamic kingdoms throughout Indonesian history. It is believed that the implementation of shariah in the past was effective in ruling the society. The last factor refers to the fact that secular-positive law has not brought about economic, social-cultural, and political improvements for Muslims in Indonesia. Based on this, Sabili views shari' ah as the solution for Indonesia's multidimensional crisis.

\section{b) It is haram (prohibited) for a woman to become a president of the country}

The issue of a woman president was presented by Sabili on three separate occasions: First in late 1998 when it became known that Megawati would be nominated as a presidential candidate as for the 1999 general elections; second at the time of President Abdurrahman Wahid impeach- 
ment in 2001; and finally in 2004 at the time of the general elections. In this regards, Sabili drew on religious texts as the basis for its rejection of having a woman (Megawati) as president. The prohibition of a woman becoming president is mainly based on the Qur' an and Hadith. God says "man is the leader for woman" (al-Baqarah: 34). Furthermore, a famous Hadith states that "A country which renders its leadership to a woman will never succeed" (Hadith transmitted by Bukhari, Tirmidzi, and Nasa'i). Another Hadith states "no great disaster (fitnah) comes after me except woman" (Hadith from Usamah bin Zaid, transmitted by Bukhari and Muslim). The prohibition of women becoming leaders has also been agreed upon by the scholars (ijma'), including Abu Hanifah, Malik, Syafi' i, Ahmad bin Hanbal, and Ibn Taimiyyah. ${ }^{112}$

Another argument commonly used against permitting a woman to become President is the historical experience of the Prophets and the $\mathrm{Ca}$ liphs. History tells us that God never delegated a woman as a Prophet and leader in this world since the Prophet Adam up to the Prophet Muhammad. What's more, during the days of the Prophet, the Caliphate, Daulah Bani Umayyah, Bani Abbas, the Islamic kingdom in Spain, as well as the Ottoman Empire, not a single woman ever became a leader or Caliph. ${ }^{113}$

According to Rizieq and Salman, the prohibition against woman becoming president is not gender discrimination as feminist groups often argue. Islam does not discriminate against women, they argue, but rather recognises that they have different roles to play in society. Hence, the reaction of some Muslims in rejecting a woman president is not discriminative but obedience to Allah. ${ }^{114}$

More clearly, Salman states that women by nature have limits in some respects which logically prevent them from carrying out cortain duties as effectively as men, or at all. The limits here are related to fitrah, their naturc and their psychology in that women menstruatc, bear children, and so forth. In essence, men and women are equal but not the same, meaning their roles, rights and obligations also differ: ${ }^{115}$ This argument is echoed by Irfan S. Awwas. Verse 34 of Surat an-Nisø̆ in his view clearly indicates that the right to lead or rule the state is only for a man. He regarded that this is not discrimination but something proscribed by religion. ${ }^{116}$

Furthermore, Salman asserts that the state under a woman president would invite nothing but disasters and problems. This, he argues, was none the more evident than during the presidency of Megawati when many crises beset Indonesia. In this respect, he used Megawati's failed government in Indonesia and proof of the above-mentioned Hadith.

Sabili's view is justified by the nature of women who are physically weaker than men and face such biological barriers as menstruation, and 
giving birth. Muslim women, it appears, have a set role in life, that is, they are encouraged to focus on household duties such as raising the children. Such a view has been presented on numerous occasions in Sabili articles.

\section{c) Polygamy is a part of shari'ah}

Polygamy has been a debatable issue among Muslim intellectuals in Indonesia for some time. Liberal Muslims, particularly Muslim feminists, tend to see polygamy as a cultural phenomenon rather than part of Islam. For them polygamy as practiced by the Prophet should be seen as social transformation towards justice in the $\Lambda$ rabic milieu. Accordingly, the essence of polygamy which is limited to four wives is actually aimed to minimize its practices since it dehumanizes women. Therefore, they claim polygamy is a form of discrimination. On the contrary, Sabili tends to defend polygamy as a part of Islam as it is clearly stated in the Qur' an (anNisč: 3). Sabili writers stress that justice is the major prerequisite of polygamy. The meaning of justice here is fulfilling the rights of women in that all of the wives receive the same amount of money, love, attention, and so on. Daud Rasyid, however, argues that justice here means 'materially" only because it is impossible for a husband to fairly share his feclings with all his wives. He refers to the example of the Prophet who was inclined to love $\Lambda$ ishah more than his other wives. ${ }^{117}$

Moreover, they refer to the Prophet's model of polygamy which is based on akhlak karmah. His polygamy was not based on manly desires but a wish to overcome social problems at that time. The Prophet's polygamy benefitcd his wives, their families as well as their clan through marriages. Therefore, the Prophet's polygamy did not discriminate against women. ${ }^{118}$

Drawing on historical examples, writers at Sabili argue that polygamy is not something odd since in the past, most of the Prophets engaged in polygamy. In Indonesia, many kings in Java, Minang, and Betawi were also polygamous. Sociologically, they argue that polygamy is necessary since the female population outnumbers the male population. According to their data, the percentage of women in Indonesia is $68 \%$ while that of men is only $32 \%$. In US, the number of women is higher eight fold than men. Research in Kenya reveals that $76 \%$ women tended to see polygamy as positive. The women regarded polygamy as sociologically beneficial if the wives help each other. ${ }^{119}$ In strengthening their argument, the writers also present interviews with polygamous wives such as the first wife of Hamzah Haz, the former vice president and wives of Puspo Wardoyo, who pionecred the program of polygamy awards in $2003 .{ }^{120}$ 


\section{d) Islamic Economy as the alternative}

The failure of the economic system in Indonesia encourages the Islamists to turn to the Islamic economic system as an alternative. Indonesia's economic woes have been made much worse by its dependence on the International Monetary Fund (IMF) which has doubled its debt. Articles in Sabili have more than once presented the view that Indonesia's dependence on IMF assistance could be overcome if the country were to implement a shari'ah economic system. ${ }^{121}$

The historical experience under Soekarno and Soeharto reveals that the secular economic concept has failed to make this country prosperous and rich. Therefore, Salman contends, Muslims should implement an economic system which is based on justice, humanity and provable results; that is the system that was implemented by the Prophet and the Caliphs after him. This system, unlike the capitalist system, does not exploit humans, because from an Islamic view, wealth and power belong to Allah and they are only entrusted to humans. Referring to the view of Yusuf alQardawi, the writer suggests that in any economic activities the doer must understand that Allah is the true owner of this universe. Thus, production is in fact exploring the materials created by God to adjust them to human needs. By such a philosophy, humans are expected to be responsible in utilizing economic sources. ${ }^{122}$

The writers in Sabili argue that the economic system in Indonesia relies heavily on ribā (interest), while God forbids Muslim to take or give riba $\bar{a}^{123}$ According to Antonio Syafi' $i$, the economic and monetary crisis which beleaguered Indonesia in particular and $\Lambda$ sian countries in general in the late Ninctics was a result of the use of ribā. Sabili strongly supports the Majelis Ulama Indonesia's (MUI) fatwa that banking interest is har $\check{m}$ m and therefore encourages Muslims to save their money in a shari'ah bank which they perceive as being free from ribā practices. ${ }^{124}$

Sabili writers argue that Muslims wish for an economic system based on shari'ah principles which could be implemented in Islamic business. Syafi'i argues that Islam is rich with economic and business altematives through fiqh muamalah (Islamic laws on [business] transactions) such as: syirkah (partnership), amanah (trust), ijärah (hire), wakālah (agency), kafălah (surety), rahn (debt), qard (guarantee), musara'ah (share-cropping), ajr (salary), and so forth. ${ }^{125}$

An interesting perspective offered by Zaim Saidi, the director of PI$\mathrm{RAC}$, is that the shari'ah banking system in Indonesia is not really Islamic enough since they have only Islamized the capitalist banking system ${ }^{126}$ What has to be developed is an Islamic economic system, namcly in real trade. Therefore he offers a notion to use gold and silver coins (dirham 
and dinar) as an alternative to paper money. There are several reasons for this: first, a similar system was practiced in the days of the Prophet because the coins possess an intrinsic value. Second, if gold and silver can apply as money then they will be universal currency for all countries. Third, as a universal currency, it does not have problems with a rate of exchange. Thus, one dinar in America is equal to one dinar in Indonesia. As a result, the rate of exchange will not be dominated by any country or currency, namely the US dollar. Fourth, using the dinar and dirham means that transactions are carried fairly since in the transaction one exchanges his dinar for other wealth that has the same value. If the dirham and dinar system can be applied, Muslims will not depend on the dollar and other currencies, thus contributing to the survival of an Islamic economy. ${ }^{127}$ It is of interest to point out, however, that the dirham and dinar system was not the invention of the Prophet since this system was previously used in the Roman ages, long before the birth of Muhammad.

\section{e) Against the perceived deviants of shari'ah}

In the name of guarding shari'ah, Sabili has heavily criticized and even labelled as "sesat" (deviant) those Islamic groups or ideas which diverge from shari'ah or authentic Islam. Among the writers, Hartono $\Lambda$ hmad Jaiz seems the most active who thrives on revealing the "mistakes" and "deviances" of Muslim figures or Islamic groups. Those who have received criticism from Sabili are Ahmadiyah, Lia Aminuddin (the founder of the Salamullah religion), NII KW IX Azzaytun, and liberal Muslim figures especially those who form part of the Liberal Islam Network (JIL). ${ }^{128}$ Here I will only focus on Sabili's criticism of liberal Muslims.

Ulil Abshar Abdallah, the coordinator of JIL, wrote a controversial article in Kompas, November, 112002 entitled "Menyegarkan Kcmbali Pemahaman Islam" (Freshening Up Our Understanding of Islam). This article has sparked the anger of radical Muslim groups including Sabili. For Sabili, Ulil's ideas not only contradict the shari'ah as presented in the Qur' an and Hadith, but also insult Allah and the Prophet. ${ }^{129}$ In his article, Ulil does not acknowledge the existence of the law of God as well as shar' ah mu'amalah (interaction between human beings). He claims that the commandments of wearing the veil (for women), cutting off the hand of the thicf, flogging and stoning (for adultery), and so forth are no longer applicable since they were merely the expression of Arabic culture. Even the prohibition against marriage between Muslim and non-Muslims is seen as not relevant any more because the verse against it is not clear. Furthermore, he asserts that the Qur' an is just half of the source of guidance for Muslim, with the other half being the human experience. ${ }^{130}$ 
In response to Ulil, Sabili seems to support Forum Ulama Ummat Indonesia (FUUI) headed by Athian Ali, who has called for the death of Ulil. Sabili cven questions the scriousness of police to process Ulil's case. For Sabili, police should investigate who stands behind Ulil, his funding, arid what political motive lies behind his efforts. ${ }^{131}$

Similarly, Irfan S. Awwas criticizes Ulil's ideas by relating a story of his time studying. He stated that Ulil studied in LIPIA between 1988-1989 and although he was a smart student he could not finish one important subject, that is Tauhïd. As a result, he did not pass and he moved to STF Drikarya and then became a student of Romo Frans Magniz Suseno. From the story, Irfan speculates Ulil's understanding of Tauhīd is far from clear or correct. ${ }^{132}$

Ulil and his colleagues in JIL regard the demands of militant Muslims to implement shari'ah as counterproductive because of the complexity between the private and public sphere. For them, religion is a private matter, and "a secular state is more promising than an Islamic state as dreamed by the fundamentalists, since it includes both the energies of piety and sins (ma'siyyat) at the same time". ${ }^{133}$ For Husaini, such an idea is misleading because shari'ah cannot exist if religion and state are separated. He argues that the implementation of shari'ah is a right of Muslims that cannot be overlooked. He emphasizes that Islam appreciates pluralism and inclusivism and this Muslim demand is a democratic one. ${ }^{1.24}$

According to Rizieq, liberal Islam draws on reason and logic not true religion, just as the deviant group the Mu'tazilah have done. To al-Anshari, for the case of cutting off of a hand, for example, JIL's argument against this Islamic regulation is weak because they do not rely on dalil syar'i (proof from the Qur'an and Sunnah). Hence, JIL simply seeks to interpret Islamic teachings based on its own desires and beliefs. ${ }^{135}$ JIL's ideas are unfounded because any arguments they use do not refer to religious texts or classical Muslim scholars in the past. Their arguments are erroneous because they do not understand Islam. For the case of cutting off of the hand of a thief, Husaini argues that all ulama - both past and present have agreed that it is an Islamic regulation which cannot be removed from Islamic law. ${ }^{136}$ Husaini views the secular movement as an attempt to subjugate Muslims. If the state implemented Islamic law and Islamic economics, the West would be worried because Muslims would no longer depend any more on their products. ${ }^{137}$

Another controversial issue raised by liberal Muslims is the making of a counter legal draft of the Compilation of Islamic law (CLD-KUI) by the team of gender mainstreaming at the Department of Religious Affairs, headed by Dr. Musda Mulia. This draft focuses on the protection of four 
values: gender, pluralism, human rights and democracy. ${ }^{138}$ One Sabili headline, "Deviant thought occupies the Department of Religious Affairs (DEPAG)", demonstrates the magazine's obvious rejection of the draft. This article is just one of many that attack the Department and the draft. For Sabili, many articles in the draft contradict shari'ah, among them as follow: ${ }^{139}$

- Marriage is conducted under the principles of willingness, equality, justice, public good (kemaslahatan), pluralism and democracy.

- A husband and a wife can make a deal to be married for a certain period of time.

- A woman is allowed to marry by her volition if she is 21 years old even without her parents and wali.

- Marriage between different religions is allowed.

- The foundation of marriage is monogamy.

- The minimum age of men and women for marriage is 19 years old.

- The Iddah (period in which a divorce must wait before marrying again applies to both husband and wife.

- Portion of inheritance (warisan) between son and daughter is equal.

Athian Ali comments that CLD-KHI is not a compilation of Islamic law but the compilation of "satanic law". It is impossible for him to call it Islamic law because it only relies on gender, democracy, pluralism and human rights without reference to the Qur'an and Sunnah. ${ }^{140}$

Many Muslim figures referred to by Sabili tend to suspect that there are political motives behind the emergence of the draft. Hussein for instance suspects that the political motive of CLD-KHI is to hinder the implementation of shari'ah in Indonesia. In the same tone, Amin Djamaluddin contends that there is a hidden power that uses Muslim youth with the goal of clouding the understanding of young Muslims, namely with regards to the Qur'an and Hadith. These allegations were strengthened by the fact that the Asia Foundation, a leading US NGO, supported liberal Muslims in completing CLD-KIII. ${ }^{141}$

The spirit to fight against Islamic liberalism and secularism brought Sabili to cover state-run Islamic institutes (IAIN), especially UIN Syarif Hidayatullah Jakarta which is vicwed by many as the nest of liberal-secular thinking, in two editions. The leading titles are apparently intended to discredit IAIN; "Selamatkan LAIN dari liberalisme dan Amoral" (Save IAIN from Liberalism and Immorality), "Mau Kemana IAIN" (Quo Vadis IAIN), "IAIN:Ingkar Allah Ingkar Nabi?(IAIN: Defying Allah and Defying the Prophet?), "Mclacak Jejak Liberal di IAIN"'(Tracing Liberalism in IAIN). 
Sabili describes IAIN as an educational institution in which strange and un-Islamic ideas are developed. By studying at IAIN, students are expected to have good akhlak and morals, to think critically and analytically to solve problem as well as to have a future vision. ${ }^{142}$ However, Sabili has noted how "crazy" thinking has afflicted the Jakarta campus. One of the more controversial issues to have arisen in recent times is the demand for the freedom not to wear jilbab, as raised by FORMACI (Ciputat Study Forum). Sabili claims that controversial thought is actually not new to IAIN. In 1970s, such a mode of thinking was initially developed by Harun Nasution, the former rector of IAIN Jakarta, who is also famous for his frecdom of thought. He encouraged freedom of thought among the academics of IAIN. This freedom was encouraged by Nurcholish Majid (wellknown as Cak Nur) also. Cak Nur for instance raised the slogan "Islam Yes, Islamic Party No!"' The trend of such thinking has been continued by students now in IAIN especially by student organizations and study clubs such as PMII, HMI, IMM, Formaci, Piramida Circle, Makar, ISAC and so forth. They have contributed to the liberalism in IAIN due to their commitment to study controversial ideologies such as Marxism, Pcrennialism, Secularism, and Rationalism. From them cmerged various terms such as Liberal Islam and Modern Islam. ${ }^{143}$

In commenting on liberalism at IAIN, Daud Rasyid asserts that frecdom of thought and rationale cannot be used to interpret things that are clear in Islam. The push for freedom of thought at IAIN is simply a misunderstanding of Islam; Islam does not forbid people from using their brains, but thinking should always be in-line with the Principles of the Qur'an and Sunnah, as well as the understandings of true Islamic scholars. From here then one is free to analyze any problem without deviating. ${ }^{144}$

In Sabili's view, the liberalism developed at IAIN tends to have a negative impact on the morality of IAIN students because they do not hold religious values. They show this tendency by revealing the fact that men and women hold hands freely on this campus without feeling ashamed. What is more, the culture of free sex can be easily found in IAIN. They support this argument by presenting the information they got from the socicty near IAIN campus telling them that many IAIN students were caught having sex and many students had abortions. This phenomenon is not exclusive to IAIN Syarif Hidayatullah Jakarta but also IAIN Sunan Kalijaga Yogyakarta and IAIN Sunan Ampel Surabaya. ${ }^{145}$ 


\section{2) Criticism of the Christians and Jews}

Criticism of and attacks on Christians and Jews have been a dominant theme in Sabili throughout the period 1998 to 2004. Besides the coverage found in such sections as Telaah Utama, Telaah Khusus, Alam Islami, and Indonesia Kita, Sabili has a special section named "Bimbingan Tauhid" (Tauhid Guidance) which contains criticism of Christian doctrines. This section is often written by FAKTA.

It is worth noting that news or coverage either of politics, economics, or conflict is often related in some way to Christians and Jews. In Sabili, they are perceived and described as the great enemy who desire to destroy Islam. In the international context, America is perceived as a Christian state and Israel as a Jewish state who collaborate in attacking Muslim countrics such as Palestine, Afghanistan and Iraq. In the national context, Sabili regards Christians as enemies who have been struggling through politics, cconomics, and socio-cultural approaches to eliminate Islam and convert Muslims to Christianity. This argument is based both on historical experience as well as religious texts which attest to their "bad" character. The famous Qur'anic verse in this regards is verse 120 from Surat alBaqarah.

Sabili has reported many cases of "Christianization" throughout Indonesia, such as in Yogyakarta, West Java, South Sulawesi, Jakarta, West Sumatra, North Sumatra, Lampung and Aceh. Sabili claims that missionaries and Christians working in Indonesia are often free to use any means to convert others, including through lying and also regularly disregard the regulations of the Department of Religious Affairs in carrying out their activities. Some of the more popular tactics employed by Christians in converting Muslims in Indonesia include: ${ }^{146}$

1. Christianization by marriage - The main objective of this approach is to corrupt Muslim Women. In order to marry a Muslim woman, the Christian pretends to convert to Islam. After marriage, the man then calls his Muslim wife to convert to Christianity.

2. Christianization by kidnapping Muslim woman, making her pregnant (rape) and then converting her to Christianity. Another method employed by Christians is to get a Muslim woman pregnant and then demand that the woman converts to Christianity if she wants the man to take responsibility for the child. An interesting abbreviation raised by Sabili in warning Muslim women is, "Beware of the three D's". That is, dipacari (dating), dihamili (getting pregnant), dimurtadkan (becoming an apostate). 
3. Christianization by providing jobs, courses and scholarships - This method targets Muslim men and women who have graduated from junior or senior high school and face difficulties in getting a job or continuing their studies. The church activists usually promise them jobs or scholarships on the condition they convert to Christianity.

4. Christianization through the provision of aid - This method largets the poor in rural areas. The missionaries act as social workers offering them aid in the form of food, rice, sugar, instant noodles, medicine, and free education. After becoming dependent upon the aid, those who wish to continue receiving aid are required to convert to Christianity. Sabili has reported cases of this in Gunung Kidul and Klaten (Yogyakarta) and in other places.

5. Christianization by pretending to be Ulama - The Christian activist passes him or herself off as a former ustadz. (religious teacher) or a family member of a leading ulama who has converted to Christianity. Through this method, he or she could raise doubts about Islam amongst Muslims.

6. Christianization by spreading drugs - Drugs are spread throughout the Muslim community, typically to Muslim students. $\Lambda$ fter becoming addicted, they are admitted to rehabilitation centres dominated by Christians where they are purported to brainwash them and indoctrinate them with Christianity.

7. Hidden Christianization through the establishment of a high institute of theology - In such an institute, Islamic studics are taught however the studies seek to unveil the weaknesses of Islam and point out supposed mistakes in the Qur'an and Hadith. An example of such an institution is STT Apostolos College.

8. Christianization by publishing Christian books in the semblance of Islamic publications - This method seeks to deceive Muslims who have little understanding of Islam so that they are tricked into reading Christian material and eventually accepting Christianity.

9. Christianization by imitating Muslims - Christians dress in Muslim clothing, such as kopiah, sarung and kerudung, and spread doubt in Islam throughout the Muslim community. Such an approach, according to Sabili, occurs in a number of places in Indonesia especially in the Betawi community in Kampung Sawah, Jakarta.

10. Christians also utilize free alternative recovery (pengobatan alternative gratis), VCD, TV and Radio, magic, hypnotism, and even spirits (as has been reported West Sumatra and Jakarta) to convert Muslims. ${ }^{147}$ 
Sabili claims that the Christians are essentially attempting to obliterate the existence of Islam in Indonesia, or at least prevent it from playing any role in public life. Prominent proof of this is the case of the Jakarta Charter. Christian groups refused to accept the inclusion of the Jakarta Charter in the 1945 constitution which includes seven words "with the obligation of the adherents of Islam to carry out shari'ah" even though it has fully been agreed to by the Board of Investigating Efforts for the Preparation of Independence (BPUPKI). They threatened to separate East Indonesia from the rest of Indonesia if the proposal was carried out. $\Lambda$ fter lobbying Hatta, the seven words were removed. In more recent times, the Persatuan Pembangunan party (PPP) and the Bulan Bintang Party (PBB) suggested incorporating the Jakarta Charter in the 1945 constitution, but once again the Christian groups rejected it. ${ }^{148}$

Another example of Christians' efforts to oppose Islam taking a place in public life is when the House of Representatives was in the process of legalizing the regulation of the national education system (RUU Sisdiknas). ${ }^{149}$ The Christian groups demonstrated in the streets insisting that the representatives vote against passing the regulation. They argued that the section on religious education does not appreciate pluralism. Although their demands were supported by the Indonesian democratic Party-Struggle (PDI-P) fraction, which was dominated by Christians, the regulation was passed. ${ }^{150}$

Sabili's strong hostility towards Christians made it evidently biased in reporting the communal conflict that took place in Ambon, Maluku from 1999 to 2000. In many of its reports on the conflict, Sabili failed to provide coverage of both sides, one of the ethical codes of press. The analysis made by political observers as well as the media was that source of the conflict was the contest for economic resources and the increasingly disproportionate distribution of political power between Muslim migrants and the indigenous Christians. ${ }^{151}$ In Sabili, however, there was a tendency to see the religious conflict as the ideological clash between Islam and Christianity. Christians were in fact described as rioters who brutally attacked and slaughtered Muslims, while Muslims were presented as victims forced to defend themselves with inferior traditional weaponry such as stones and swords. ${ }^{152}$ America and Israel were believed to have supported Christian groups in Maluku with weapons. Siding with the Muslims, Sabilicalled on Muslims to go for jihad to help their brothers against the kuffar (infidels) in Maluku.

With regards to the Jews, Sabili calls on all Muslims to boycott Zionist and American products following the fatwa of Sheikh Yusuf al-Qardawi that buying their products is haram since their money contributes to the 
killing of Muslim Palestinians. ${ }^{153}$ In presenting a negative image of the Jews, Sabili refers to the following verses of the Qur'an: ${ }^{154}$

1. Jews are fond of breaking agreements and changing the facts (al-Baqarah: 100, al-Baqarah: 89, al-Anfǚl: 56, and an-Nisǔ: 155).

2. Jews tend to engage in slander and deception with the aim of raising doubts about Islam (Ali Imran: 72, and al-Maidah: 49-50).

3. Jews usually make false allegations and collaborate with the infidel (kafir) (an-Nisč::51-52).

4. God forbids Muslims to take the Jews and Christians as guardians and to trust their intentions (al-Mumtahanah: 13, al-Maidah: 51-56, and alBaqarah: 120).

5. The Prophet was strict in dealing with the tricks and slander of the Jew (al-Ahzab: 21).

According to Nurasyid, the Christians' and Jews' strategy of destroying Islam has changed into the so-called ghazwul fikri (wat of thought). It is intended to raise doubts about Islam and bring Muslims away from Islamic guidance. In general the four S's - that is songs, sports, sex and study - destroy Islam. ${ }^{155}$ Moreover, generations of Muslims are also being destroyed by drugs. ${ }^{156}$

\section{3) Opposition to America}

Opposition to the West - in particular America - has been a common theme in Sabili. Besides a special section entitled 'Alam Islamy' (Islamic world), which deals with the tragedies that afflict the Muslim world, Sabili reports cases that show the role America plays in creating instability and conflict in Muslim countries including Indonesia.

Following the collapse of the Soviet Union, America became the lone stperpower, and thus has appointed itself as the world police which has the right to intervene in other countries affairs, especially in Muslim countries. To Sabili, the political policies used by America are influenced by Samuel Huntington who views Islam as the greatest enemy of America. ${ }^{157}$ According to the editor Nurdi, America wants to dominate the world through gold, glory and gospel and Islam is seen as a potential threat to achieving this goal. Therefore America utilizes whatever methods it can to hinder the implementation of formal shari' ah and destroy militant Muslim movements in the Muslim world as well as to colonize rich Muslim countries for their own interests. ${ }^{158}$

The invasion by US troops and its allies of Iraq was heavily criticized and condemned by Sabili. During the invasion and the war, Sabili actively reported the latest developments in the war. As an advocate for Muslims, Sabili described the battle in Iraq as a Jihad against the enemy of Islam and 
regularly reported the cruelty of US troops in killing Iraqi civilians and children, bombing their houses, and treating Iraqi prisoners like animals. Sabili furthermore reinforced the fact that America lied about the existence of weapons of mass destruction in Iraq. ${ }^{159}$ The invasion of Iraq, in Sabili's view, is actually motivated by the interest to seize control of the oil resources in Iraq in consideration of their own dwindling oil supplies. Instead of bringing freedom and democracy, the magazine contends, America and its allies have only brought suffering to the Iraqi people. ${ }^{160}$

As part of its efforts to destroy Islam, America has alleged that a number of Islamic individuals and groups are in fact terrorists. ${ }^{161}$ This allegation initially found momentum in the wake of the attack on the World Trade Center on September $11^{\text {th }} 2001$. As a direct implication of this attack, America began to link the al-Qaeda network with Islamic movements and figures in Asia especially Indonesia. The bombings in Bali, the Marriot Hotel, McDonalds, and the Australian Embassy have brought America's war on terrorism to Indonesia, with the country being labelled a haven for terrorist activities. As a result, many Muslim activists such as Abu Bakar Ba'asyir have been arrested and jailed without sufficient evidence.

Sabili responds to such claims by the United States by describing the bombings and terrorist issue as an American conspiracy to destroy Islam around the world. Anis Matta, the general secretary of PKS, as quoted by Salman, states that America is seeking to eradicate and destroy Islam by eliminating Islamic movements. ${ }^{162}$ That is because America is concerned that if such movements are not contained, they will become a threat to US domination and interests in Asia. ${ }^{163}$

Other methods have been employed by America to destroy Islam. Referring to the New York Times, Sabili reported that the Pentagon has prepared special steps to achieve this goal. First, the United States will try to reduce the function of the Mosque as the centre of Muslim movements. Second, it will influence the religious education curriculum in countries around the world, especially in countries where Muslims represent the majority. Last, the Pentagon will finance educational institutions that favour or adopt western model of education. ${ }^{164}$

In light of this, the writers of Sabili often question and suspect the Ford Foundation and Asia Foundation (TAF) of being the puppets of the US administration who are being used to weaken Islam by supporting certain Muslim groups, such as the liberals, and rejecting others. TAF in particular has supported liberal Muslims who actively push such issues as gender equity, pluralism, human rights and democracy in Indonesia. TAF has further been giving financial aid to syir'ah magazine, one of the leading liberal magazines in Indonesia. $^{165}$ 


\section{Notes}

1. With respect to political liberation, Habibie responded to demands for democratization by promising to implement a four-step process: (1) The passing by Parliament - of new laws to enable frec and fair elections and open party competition (early 1999); (2) calling a special session of the Consultative Assembly at the end of 1998 to set a new date for clections; (3) holding parliamentary elections in the middle of 1999; and (4) calling a regular session of the Consultative Assembly at the end of 1999 to elect a new president and vice president and set the "broad outlines of state policy," as mandated by the 1945 constitution, for the next five years. He also announced that the restrictive press law was to be withdrawn and that in the meantime all media entities in Indonesia would be free to operate as they pleased. See R. William Liddle, "Indonesia's Unexpected Failure of Leadership" in Adam Schwarz and Jonathan Paris (eds.), The Politics of Post-Suharto Indonesia (New York: Council on Forcign Relations Press, 1999), p. 26.

2. Martin E. Appleby and R. Scott Appleby, Fundamentalism Observed (Chicago: the University of Chicago Press, 1991), p. 9.

3. Bahtiar Effendi, "Islam Politik Pasca Soeharto Di Indonesia," Refleksi 5, No. 2:2003, p. 3.

4. Arskal Salim and Azyumardi Azra, "The State and Shari'ah in the Perspective of Indonesian Legal Politics", an introduction in Shari'ah and Politics in Modern Indonesia eds. Arskal salim and $\triangle$ zyumardi Azra (Singapore: Institutc of Southeast Asian Studies, 2003), pp. 1-3.

5. Salim and Azra, "The State and Shari"ah," pp. 1-3.

6. Bahtiar Effendy, Islam and the Statc in Indonesia (Singapore: Institute of Southeast Asia Studies, 2003), pp. 217-218.

7. Salim and Azra, "The State and Shari'ah,"p. 4

8. This issue covered comprehensively in Gerakan Salafi Radikal di Indoncsiacdited by Jamhari and Jajang Jahroni (Jakarta: Rajawali Press, 2004).

9. For a detailed explanation see Saiful Mujani and R. William Liddle, "Politics, Islam, and Public Opinion," Journal of Democracy, Vo. 15, No. 1 January 2004, pp. 113$116,118-120$.

10. The intellectuals who can be included in the first sidc are Ramakrisna, Bahtiar Effendy and Azyumardi Azra while the second are Robert W. Hefner and Martin Van Bruinessen. Azra for instance maintains that the increase in Islamic Radicalism is basically the result of government failure to enforce the law and to solve the socio-religious conflicts, and This article is taken from the author's Master of Arts thesis, submitted to the P'ostgraduate Faculty August 2005. as a result of the abrupt decline of central government authority. See Azyumardi Azra, Islamic Militant Movements in Southeast Asia; Socio Political and Historical Contexts, a paper presented in the International Seminar on Islamic Militant Movements in Southeast Asia held by PBB and INIS-Universiteit Leiden, July 22-23, 2003, Jakarta Mulia Hotel. Hefner and Bruinessen also admit such internal factors, yet they stress that Islamic radicalism in Indonesia has come to its prominence with the significant contribution of financial assistance from the Saudi Arabian authoritics. For further information on this issue see Bruinessen, "The Genealogies of Islamic Radicalism," p. 118.

11. Akh. Murakki, "Islamic Radicalism in Southeast Asia: With Special Reference to the Alleged Terrorist Organization, Jama'ah Islamiyah", A/-Jamiah, 42, 1: 2004, p. 69. 
12. William A. Gamson, "Constructing Social Protest," in Steven M. Buechler and F. Kurt Cylke Jr. (cds.), Social Movement: Perspectives and ISsucs (California: Mayfield Publishing Company, 1997), p. 229.

13. Krishna Sen and David T. Hill, Media, Culture, and Politics in Indonesia (UK: Oxford University Press, 2000), pp. 69-70.

14. Ibid.

15. Dalc F. Eickclman and James Piscatory, Muslim Politics (Princeton: Princeton University Press, 1996), p. 5.

16. Martin Van Bruinessen, Post-Suharto Muslim Engagements with Civil Society and Democratization, paper presented at the Third International Conference and Workshop "Indonesia in Transition", organized by the KNAW and Labsosio, Universitas Indonesia, August 24-28, 2003. Universitas Indonesia, Depok, pp. 57.

17. Martin Van Bruinessen, Post-Suharto Musfim Engagemonts, pp. 5-7.

18. This institute was established and devcloped by young NU intellectuals. It aims to create a critical society and a free public sphere through dialog, research, and publication. Indigenization of Islam and cultural studies are the prominent issues promoted by this institute.

19. The circulation of this magazine is around 10.000 copics per-cdition. Sce Agus Sudibyo, "Mutu Jurnalistik Media Islam Radikal Lemah", in <www. Islamlib.com>.

20. Agus Muhammad, "Quo Vadis Media Islam Moderat?," <www.islamlib.com>.

21. The History of Sabili Magazine, p. 1.

22. Such policies included: 1. The announcement of the marriage law in 1973 which attracted strong criticism from many Islamic organizations. 2. Legalization of prostitution and gambling for the sake of economic growth. 3 . The prohibition of wearing jilbab in schools. 4. The promotion of family planning. 5. The legalization of the alcohol industry. Sce M. Rusli Karim, Negara dan Peninggiran Istam Politik (Yogyakarta: Tiara Wacana, 1999), p. 119-121.

23. Faisal Ismail, "Pancasila as the Solc Basis for all Political Parties and for All Mass Organizations; an Account of Muslims' Responses:" Studia Islamika 3, 4: 1996, p. 10.

24. Faisal Ismail, "Pancasila as the Sole Basis," p. 3.

25. Abdul Syukur, Gerakan Usroh di Indonesia;Pcristiwa Lampung 1989 (Yogyakarta: Ombak, 2003), p. 31.

26. Karim, Negara dan Peminggiran Istam Politik, p. 162.

27. Agus Muhammad, "Jihad Lewat Tulisan," Pantau, July 2001: p. 11.

28. Muhammad, "Jihad Lewat Tulisan," p. 11.

29. Interview with \%ainal Muttaqin, 30 June 2005.

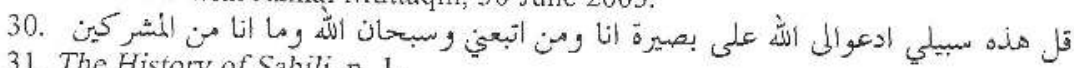

31. The History of Sabili, p. 1.

32. In the verse, the word ad'u (to call/to do da'wah) is in the prescnt tense (fi'il mudfari) which denotes a habitual action. Sccond, ila-Allah means that preacher should realize that the goal will lead to eternity in heaven if it is sincerely done to please Allah, not others. Third, 'ala baćirah means that a preacher (da'i) should have argumentation (hujjah) with a clcar concept in doing da'wah. Fourth, ana wa manittaba'anș means that Muslim should play a role of da'wah leadership. The da'wath lcadership role mcans that there should emcrge a sincere lcader who can communicate da'wah to Muslims. Given such interpretation, Sabili is mainly intended to be the media of da'wah. See The History of Sabili, pp. 1-2.

33. Sen and Hill, Media, Culture and Politics in Indonesia, p. 12. 
34. Ibid., p. 60 .

35. Zainal Muttaqin, interview, 30 June 2005

36. Rahmat Abdullah is a traditional Betawinese Islamic scholar who had the same vision with da'wah movement activists in campuses. He was a contemporary of Zainal Muttaqin who developed the Tarbiyah movement in the 1980s. In 1999 he is appointed as the head of the Syura board of PKS. He passed away in June 2005.

37. The History of Sabili, p. 2

38. The most prominent Muslim intellectuals at that time were Nurcholish Majid (Cak Nur) and Abdurrahman Wahid (Gus Dur).

39. The History of Sabili, p. 2.

40. Interview with Zainal Muttaqin, 30 June, 2005.

41. The History of Sabili Magazinc, p. 2.

42. Zainal Muttaqin, Interview, 30 June 2005.

43. The History of Sabili Magazinc, p. 2.

44. Salman, Intervicw, 15 March 2005. Scc also "Assalamu Maikum". Iftitah. Sabili No. 1, 30 June 1998 , pp. 2-3.

45. The History of Sabili, p. 3.

46. Ibid.

47. See Sabili, No.3 vol. VI 4 Augusts 1998, p. 2.

48. Agus Muhammad, "Jihad Lewat Tulisan", Pantau, July 2001, p. 12.

49. Ibid. pp. 1-2.

50. Sabili, No. 3 vol. VI 4 Augusts 1998 , p. 2 .

51. Ibid. This mecting was hold in Wisma PHI Cempaka Putih.

52. The History of Sabili, p. 3.

53. Zainal Muttaqin, Interview, 30 June 2005.

54. Intcrvicw with Salman, 15 March 2005.

55. The History of Sabili, p. 3.

56. Sabili No.1, vol. VI, 30 June 1998, p. 6-7.

57. Ibid.

58. Sabili No. 3, vol. 1V, 14 August 1998, p. 3-4.

59. Ibid.

60. Sabili No. 4, vol. VI, 2 September 1998 , p. 8-9.

61. Zainal Muttaqin, Interview, 30 June 2005.

62. Sabili No. 5, vol. VI, 16 September 1998, p. 8-9.

63. Sabili No. 7, vol. VI, 14 October 1998, p. 4-5.

64. Astraatmaja claims that news presented in Sabili magazine is often inaccurate, unfair and biased. However, such criticism is countered by Salman arguing that Sabili is a media of advocacy and this is eligible in press theories. See Agus Muhammad, "Jihad Lewat Tulisan," p. 14.

65. Sabili Doc. The History of Sabili.

66. Ibid.

67. Oliver Roy, The Failure of Political Islam, (London: I.B.Taurus Publishers, 1994), pp. 35-36.

68. See Sabili No. 4 XI, 11 September 2003.

69. Zainal Muttaqin, interview, 30 June 2005.

70. Zainal Muttaqin, Intervicw, 3 June 2005.

71. Salman, interview, 15 March 2005.

72. Rivai Hutapea, interview, 26 April 2005.

73. Retired in 2001. 
74. Martin Van Bruncissen, Genealogies of Islamic Radicalism in Post-Socharto Indonesia, <http://www.let.uu.nl/ martin.vanbruinessen/personal/publications/ gencalogies_islamic_radicalism.html>, p. 8.

75. Interview with M. Nurkholis Ridwan, 26 May 2005.

76. Salman, interview, 15 March 2005.

77. Rivai Hutapea, interview, 26 April 2005.

78. Herry Nurdi, interview, 26 April 2005.

79. For further information sec Ade Armando, "Citra Kaum Pembaharu Islam Dalam Propaganda Media Dakwah” in Ulumul Qur'an, IV:3, 1993.

80. For further information, see Jajang Jahroni, "Defending the Majesty of Islam: Indonesia's Front Pembela Islam (FPl) 1998-2003," Studia Islanika, 11, No. 2 (2003): pp. 197-255.

81. For further information sce Jamhari and Jajang Jahroni (ed), Gerakan Salafi Radikal di Indonesia (Jakarta: Rajawali Press, 2004), pp. 47-84.

82. KISDI was founded in 1987 by Ahmad Sumargono, Lukman Harun, and others in the most conservative wing of the DDII. KISDI was originally established to heighten Indonesian sympathy for the plight of the Palestinians. After the fall of Socharto, KISDI intensely promoted the implementation of shari'ah in media and radio.

83. See Robert W. Hefner, Civil Islam: Muslims and Democratization in Indonesia, (UK: Princeton University Press, 2000), pp. 109-110.

84. See further Jamhari, "Mapping Radical Islam", pp. 161-203.

85. See Liddle, "Mcdia Dakwah Scripturalism: One Form of Islamic Political Thought and Action In New Order Indonesia" in Toward a New Paradigm: Recont Developmont in Indonesian Islamic Thought, (Arizona: Arizona State University, 1996), p. 328.

86. Sce Endang Turmudi and Riza Sihbudi (ed), Islam dan Radikalisme di Indoncsia (Jakarta: LIPI Press, 2005), pp. 209-224.

87. Interview with Zainal Muttaqin, 3 June 2005

88. One of the leading business research institutions in America

89. Bogor, Tangerang: and Bekasi.

90. Damanik reveals that Tarbiyah Movement has grown and expanded in the secular universities such as UI, ITB, IPB, UGM, and so on. The characteristic of the cadres of this movement is young and cducated. See Ali Said Damanik, Fenomena Partai Keadilan: Transformasi 20 Tahun Gerakan Tarbiyah di Indonesia (Jakarta: Teraju, 2003).

91. Uki, Interview, 26 May 2005

92. Ibid.

93. Rivai Hutapca, interview, 26 April 2005.

94. Uki, interview, 26 May 2005

95. Ibid.

96. Daud Rasyid, "Syariah," Sabili No.10 Vol. VIII, 1 November 2000, pp. 74-75.

97. Agung Pribadi, "Syariat Islam: Mengapa Tidak?" Sabili. No. 25, vol. VIII, 6 June 2001, pp. 30-31.

98. Topo Santoso. "Bersatu Menegakkan Syariat Islam," Sabili No.1. vol. IX, 4 July 2000 , pp. 76-77.

99. Habibullah Lc., "Ilukum Islam dan Jaminan rasa Aman," Sabili No.18. vol. X, 28 February 2001. 
100. Freedom House, Freedom in the World, 2001, quoted by Saiful Mujani, "Syariat Islam Dalam Perdebatan" in Burhanuddin (ed.) Syariat Islam: Pandangan Muslim Liberal, (Jakarta: JL and TAF, 2003), pp. 25-26.

101. Al-Chaidar, "Meneropong Kondisi Umat Islam Pasca SU-MPR 1999", Sabili No. 10 Vol. VII 3 November 1999 , p. 63.

102. M.U. Salman, "Mengusir Momok Negara Islam," Sabili No. 13. VI 6 January 1999, pp. 26-27.

103. M.U. Salman, "Hidupkan Kembali Piagam Jakarta," Sabili No.16 VOL. VI 24 February 1999, p. 22.

104. Salman, "Piagam Madinah," Sabili No.7 VOL, 1X 26 September 2001, p. 3.

105. Salman, "Hidupkan kembali Piagam Jakarta,"p. 20.

106. Zainal Muttaqin, "Mengembalikan Piagam Jakarta, Mengapa Tidak?," Sabili No.5. Vol. VIII, 23 August 2000.

107. Salman, "Hidupkan Kembali," pp. 21-22.

108. Rivai Hutapea, "Hukum Islam Lebih Awal di Indonesia," Telaah Utama in Sabili No.16 Vol. VI, 24 February 1999 , pp. 23-26.

109. Rivai Hutapea, "Esensi Piagam Madinah", Sabili No.2.VII 14 July 1999, pp. 5152.

110. Nurcholish Madjid, "Potential Islamic Doctrinal Resources for the Establishment and Appreciation of the Modern Concept of Civil Society" in Nakamura ct.al. (ed), Islam and Civil Socicty in Southcast Asia (Singapore: ISEAS, 2001), p. 156.

111. Bahtiar Effendy, Islam and the State in Indonesia, (Singapore: ISEAS, 2003), p. 218.

112. KH. Firdaus, "Megawati Haram Jadi Presiden", Sabili No. 16 IX 31 January 2001, pp. 14-15.

113. Tbid.

114. Al-Habib Muhammad Rizieq bin Husein Syihab, p. 86-87 and M.U. Salman, "Presiden Wanita?," Sabili No. 18. XI 26 March 2004, p. 14.

115. Salman, "Presiden Wanita?," p. 14.

116. Irfan S. Awwas, "Halal Haram Presiden Wanita," Sabili No.25. XI 2 July 2004, pp. 41-42.

117. Salman, "Poligami Yes, Ikhtilat No!", Sabili No. 2. XI 14 August 2003, p. 15.

118. A. Ruhendi Saifullah, "Poligami Rasulullah: Scbuah Model". Sabili No. 8. 4 October 2000 , pp. 22-23.

119. Hepi Andi, "Mercka Menyerang Syariat Poligami," Sabili No. 2 XI 14 August 2003. pp. 100-102.

120. "Suara Isteri Pertama," Sabili No. 22. V1 19 May 1999, pp, 55-56.

121. Misbah, "Memerangi Sistem Riba", Sabili No. 5. IX 29 August 2001, pp. 68-69.

122. M.U. Salman, "Sekarang Waktunya Ekonomi lslam!", SabiliNo. 14. VI 20 January 1999, p. 12-14.

123. (Sec the Qur'an,: Surats ar-Rum:39; an-Nisa': 160-161; Al-Imran: 130); and alBagarah:278-279.

124. Sec Eman Mulyatman, "Bunga Bank Haram: MUI Jangan Plin Pan," Sabili No. 13..XI 15 January 2004, pp. 54-58 and Hardianto, "Riba dari Masa ke Masa", p. 61.

125. Eman Mulyatman, "Bunga I3ank Haram," p. 56.

126. See Intervicw with \%aim Saidi, Emas dan Perak, Mata Uang Universal, Sabili No. 11 VOI.X 12 Desember 2002, pp. 78-80 and Zaim Suidi, Melawan KapitalisMaterialisme, Sabili No. 11 VOL.XI 18 Desember 2003, pp. 94-95. 
127. Rivai llutapca, "Lawan Dollar dengan Dinar", Sabili No.11. X 26 Desember 2002 p. 87 and 89.

128. See Hartono Ahmad Jaiz, "Membedah Anatomi Aliran Sesat", Sabili No. 9. XI 2003 Sejarah Emas Muslim Indonesia; Misbah, "Menggugat Kesesatan Ahmadiyah", Sabili No.3.VIII 26 July 2000; Rivai Hutapea, "Padamkan Bara Gerakan Sesat", Sabili No.20. IX 4 April 2002; and Rivai Hutapea, "Membongkar Kedok LDII", Sabili No.26. IX 27 Junc 2002.

129. Sec Hartono Ahmad Jaiz, pp. 150-151

130. Ulil Abshar Abdallah, "Menyegarkan Kembali Pemahaman Islam", Kompas. 11 November 2002.

131. M. Adnan Firdaus, "Fatwa Mati" Buat Yang Usil", Sabili No.12. X 2 January 2003, pp. 106-107 and Eman Mulyatman, "Kasus Ulil Menyesakkan Kembali Pemikiran Umat Islam," Sabili 30 January 2003, p. 110.

132. Irfan S. Awwas, "Tauhid Iblis", Sabili No.12. X 2 January 2003, pp. 84-85.

133. Kelik M. Nugroho, "Islam Liberal versus Islam Literal," Tempo, No. 38/XXX (19-25 November 2001), p. 96.

134. Misbah, "JIL: Kebebasan yang Kebablasan", Sabili No. 15. IX 25 January 2002, pp. 74-78.

135. Ibid., p. 77.

136. Ibid., p. 78

137. Ibid.

138. Tim Pengarusutamaan Gender, Pcmbaruan Ifukum Islam: Counter Legal draft Kompilasi Hukum Islam (Jakarta: TPG DEPAG RI, 2004), p. 3.

139. Rivai IJutapea, "Pikiran Sesat Kuasai Departemen Agama," Sabili No.8. XII 5 Novembar 2004, pp. 17-20.

140. Ibid., p. 19

141. Ibid., pp. 19-20.

142. Rivai Hutapea, "Selamatkan IAIN dari Liberalisme dan Amoral," Sabili No.25. IX 13 June 2002, pp. 72-73.

143. Ibid., pp. $74-75$.

144. Ibid., pp. 74-75 and M. Nurkholis Ridwan, "Mclacak Jejak Liberal di IAIN," Sabili No.25. IX 13 June 2002, p. 82.

145. Rivai Hutapea, "Selamatkan IAIN," pp. 76-77.

146. Rivai Hutapea, "Scpuluh Taktik Pemurtadan", Sabili, No.24. IX 24 May 2002, pp. 79-81.

147. Rivai Hutapea, "Jin Salibis Murtadkan Umat," Sabili No.23. X 5 June 2003, pp. $11-104$.

148. Rivai Hutapea, "Kaum Salibis Menjegal Islam: Dari P'iagam Jakarta Sampai RUU Sisdiknas," Sabili No. 25. X 3 July 2003, pp.23-29.

149. The section in this regulation state that the student has a right to receive religious education according to his religion from a teacher of the same religion. See Rivai Hutapea, "Misi Salibis I ladang Sisdiknas," Sabili No. 19. X 10 A pril 2003, p. 1617

150. Rivai Hutapca, "Kaum Salibis Menjegal Islam," p. 29.

151. Azyumardi Azra, "Communal Riots in Indoncsia: The Decline of Indonesian Nationalism and the Risc of Separatism" in Communal Conflicts in Contemporary Indonesia, (Jakarta: I'usat Bahasa dan Budaya IAIN Jakarta), pp. 87-91.

152. M. Lili, N.A., "Selamatkan Ambon, Kobarkan Darah Syahidmu," Sabili No. 5 VOL.VII 25 Augus 1999, pp, 26-30. 
153. M.U.Salman, "Boikot Produk Yahudi," Sabili No. 11 VOL.VIII 15 November 2000, pp. 74-78.

154. M.Lili NA, "Yahudi Sepanjang Zaman," Sabili No.11 VOL. VII 17 November 1999, pp. 24-25.

155. First, songs of an unreligious nature are produced that make Muslims forget their religion. Second, Muslims are made busy with the latcst sporting news and events which makes them too lazy to pray. Third, a culture of free sex is propagated through TV programs and other mediums, and as a result Muslims ignore their religious values. Lastly, the cnemies of Islam struggle to have Islamic studies removed from school curricula, replacing it with orientalist, secularist and material perspectives on life and religion. As a result, Muslims' understanding of Islam is limited to the point that Islam is seen as something strange by Muslims themselves. See Mulyadi Nurasyid, "Ghazwul Fikri," Sabili No. 9 Vol. VII 20 October 1999, pp. $79-80$

156. Mulyadi Nurasyid, "Ghazwul Fikri," p. 80.

157. "Misi Amerika di Indonesia," Sabili 1st edition (Kebangkitan), Junc 1998, p. 41.

158. Herry Nurdi, "Urut Kacang Gerakan Islam," Sabili No.7 Vol. XI 23 October 2003, pp. 103-105.

159. Herry Nurdi, "Berdusta Demi Perang," Sabili No.8 Vol.XII 5 November 2004, pp. 98-103.

160. Herry Nurdi and Artawijaya, "Mengharap Pahlawan Mendapat Penjajah," Sabili No.8 Vol.XII 5 November 2004, pp. 110-111.

161. See M.U. Salman, "Ini Dia Musuh gerakan Islam," Sabili No. 8 VOL. VIII 4 October 2000, pp. 74-76, Irfan S. Awwas, "Siapa Agen Teroris di Indonesia," Sabili No. 16 VOL.IX 8 February 2002, pp. 68-69, Mohammad Safari, "Hegemoni ASZionis dan Gerakan Islam," Sabili No.19 VOL.X 10 Aprial 2003, pp. 36-37.

162. M.U. Salman, "Ini Dia Musuh gerakan Islam," Sabili No. 8 VOI. VIII 4 October 2000, p. 75

163. Herry Nurdi, "Urut Kacang Gcrakan Islam," pp. 103-105.

164. Ilerry Nurdi, "Menguak Misteri Konspirasi; Setahun Bom Bali," Sabili No. 7. IX 23 October 2003, pp, 100.

165. Rivai Hutapea, "Dari Pluralisme Sampai Gender," Sabili No.10. XII 3 December 2004 , p. $23-25$ 


\section{Bibliography}

Abdallah, Ulil Abshar. "Menyegarkan Kembali Pemahaman Islam." Kompas, Nov. 11, 2002.

AC. Nielsen. The Readership Survey, Media Measurement Services, 2000-2001, 20012002.

al-Asymawi, Muhammad Sa'id. Against Islamic extremism; the writings of Muhammad Sa'id al-Ashmawy. Florida: University press of Florida, 1998.

Anderson, Benedict. Imagined Community: Reflections on the Origin and Spread of Nationalism. London-New York: Verso, 1983.

Anwar, M. Syafi' I Anwar. Pemikiran Dan Aksi Islam Indonesia: Sebuah Kajian Politik Tentang Cendekiawan Muslim Orde Banu. Jakarta: Paramadina, 1995.

Armando, Adc. "Citra Kaum Pembaharu Islam Dalam Propaganda Media Dakwah" in Ulumul Qur'an 4, 3: 1993.

Azra, Azyumardi and Irwan Abdullah. Islam dan Akomodasi kultural in Ensiklopedi Tematis Dunia Islam: Asia Tenggara. Jakarta: PT. Ichtiar Baru Van Hocve, 2002.

Azra, Azyumardi. "Communal Riots in Indonesia: The Decline of Indonesian Nationalism and the Rise of Separatism" in Communal Conflicts in Contcmporary Indonesia, edited by Chaider S. Bamualim et.al., Jakarta: Pusat Bahasa dan Budaya IAIN Jakarta.

—."Muslim Indonesia:Viabilitas "Garis Keras." Gatra, Special Edition, 2000.

- Islamic Militant Movements in Southeast Asia; Socio Political and Historical Contexts. A paper presented in International Seminar on Islamic Militant Movements in Southeast Asia held by PBB and INIS-Universiteit Leiden, July 2223, 2003, Jakarta Mulia Hotel.

Barton. Greg. Indoncsian Islam and The Emergence of Radical Jihadi Islamism <http: hww.trowelandsword.org.au/march1200304art2.htmls.

Bruinessen, Martin Van. Post-Suharto Muslim Engagements with Civil Society and Democratization. paper presented at the Third International Conference and Workshop "Indonesia in Transition", organized by the KNAW and Labsosio, Universitas Indonesia, August 24-28. 2003. Universitas Indonesia, Depok.

Bruneissen, Martin Van, Genealogies of Islamic Radicalism in Post-Soeharto Indonesia, <http://www let.uu.nl/ martin.vanbruinessen/personal/publications/ genealogies islamic_radicalism.html .

Damanik, Ali Said. Fenomena Partai Keadilan: Transformasi 20 Tahun Gerakan Tarbiyah di Indonesia. Jakarta: Teraju, 2003.

Effendi, Bahtiar. "Islam Politik l'asca Soeharto Di Indonesia." Refleksi 5, 2: 2003.

-, Islam and the State in Indonesia. Singapore: Institute of Southeast Asia Studies, 2003.

- Islam dan Negara: Transformasi Pemikiran dan Praktik Politik Islam di Indonesia. Jakarta: Paramadina, 1998.

Eickelman, Dale F. "I'rint, Islam and The Prospects for Civic Pluralism: New Religious Writings and Their Audiences." Journal of Islamic Studies 8, 1 (1997): 43-62.

-, and Anderson, Jon W. Now Mcdia in The Muslim World; The Emerging Public Sphere. USA: Indiana University Press, 1999.

—, and James Piscatory. Muslim Politics, Princeton: Princeton University Press, 1996.

Esposito, John L. The Is/amic Threat; Myth or Reality. New York: Oxford University Press, 1992.

Gamson, William A. et. al., "Media Images and the Social Construction of Rcality,"Annual Revicw of Sociology, Vol.18 (1992): 373-393. 
Gamson, William A. "Constructing Social Protest," in Steven M. Bucchler and F. Kurt Cylke Jr. (eds.). Social Movement: Perspectives and Issues. California: Mayfield Publishing Company, 1997.

Habermas, Jurgen. Between Facts and Norms. Cambridge, Mass.: MIT Press, 1996.

Hefner, Robert W. "P'rint Islam: Mass Media and Idcological Rivalries Among Indonesian Muslims," Indoncsia, Cornell University, no. 64, Oct. 1997.

-, Civil Islam: Muslims and Democratization in Indonesia, Princeton, NJ: Princeton University Press, 2000.

Hatiyah, Nurlita, Tafsir Kebencian Dalam Majalah Sabili. Undergraduate Thesis, Faculty of Theology and Philosophy, Syarif I lidayatullah State Islamic University, 2004.

Ismail, Faisal. "Pancasila as the Sole Basis for all Political Parties and for All Mass Organizations;an Account of Muslims ${ }^{2}$ Responses." Studia Islamika, 3, 4: 1996.

Jamhari and Jajang Jahroni (cds). Gerakan Salafi Radikal di Indonesia. Jakarta: Rajawali Pcrs, 2004.

Jamhari. "Mapping Radical Islam in Indonesia." Studia Islamika 10, no. 3 (2003): 1-25. Jahroni, Jajang, "Defending the Majesty of Islam: Indonesia's Front Pembela Islam (FI'I) 1998-2003," Studia Islamika, 11, No. 2(2003): 197-255

Kallen, Iloracc M. Encyclopedia of the social sciences, vol. XIII-XIV, New York: The McMillan Company, 1963.

Karim, M. Rusli. Negara dan Peminggiran Islam Politik. Yogyakarta: Tiara Wacana, 1999.

Liddle, R. William. "Indonesia's Unexpected Failure of Leadership." Schwarz Adam and Jonathan Paris (cds). The Politics of Post-Suharto Indonesia. New York: Council on Foreign Relations Press, 1999.

- "Media Dakwah Scripturalism: One Form of Islamic Political Thought and Action in New Order Indonesia" in Toward a New Paradigm: Recont Developmont in Indonesian Islamic Thought. Arizona: Arizona State. 1996.

—, "The Islamic Turn in Indonesia: A Political Explanation", Jeff Haynes (ed.), Religion, Globalization, and Political Culture in the Third World. Britain: Macmillan Press LTD, 1999.

Madjid, Nurcholish, "Potential Islamic Doctrinal Resources for the Establishment and Appreciation of the Modem Concept of Civil Society" in Islam and Civil Society in Southeast $A$ sia. Edited by Nakamura et.al. Singapore: ISEAS, 2001.

Marty, Martin E. and Apleby, R. Scotl. Fundamentalisms Observed. Chicago and London: The University of Chicago Press, 1994.

Muhammad, Agus. Quo Vadis Media Islam Moderat? 21 Mar. 2005. <www.islamlib.com>.

Mujani, Saiful, and R. William Liddle. "Politics, Islam, and Public Opinion," Journal of Democracy, 15, 1: Jan. 2004.

Mujani, Saiful. "Syariat Islam Dalam P'erdebatan" in Burhanuddin (cd.) Syariat Islam: Pandangan Muslim Libcral. Jakarta: JIL, and TAF, 2003.

Muzakki, Akh. "Islamic Radicalism in Southeast Asia: With Special Reference to the Alleged Terrorist Organization, Jama'ah Islamiyah." Al-Jamiah, 42, 1: 2004.

Nugroho, Kelik MI. "Islam Liberal versus Islam Literal." Tempo, 38. XXX.

O'Shaughessy, Michael and Stadler, Janc. Media and society; an Introduction. UK: Oxford University Press, 1999.

Raharjo, Dawam, "Radical vs. Liberal Islam", Tempo, Jan. 27, 2003.

Robinson, Francis. "Technology and Religious Change: Islam and the Impact of Print." Modern Asian Studics, 27.1: 1993. 
Roy, Oliver. The Failure of Political Islam. London: I.B. Taurus Publishers, 1994.

Roy, Olivier. Globalized Islam: The Search for a New Ummah. London: Hurst Company, 2004.

Sabili Doc. The History of Sabili Magazine.

Salim, Arskal and Azyumardi Azra. Shari'a and Politics in Modem Indoncsia. Singapore: Institute of Southeast Asian Studies, 2003.

Schwarz, Adam. A Nation in Waiting: Indonesia's Search for Stability. Australia: Allen and Unwin, 1999.

Sen, Krishna and David T. Hill. Media, Culture and Politics in Indonesia. UK: Oxford University Press, 2000.

Sidahmed, Abdel Salam and Anoushiravan Ehteshami (eds.). Islamic Fundamentalism. Westview Press, 1996.

Sudibyo, Agus. "Mutu Jurnalistik Media Islam Radikal Lemah." <www. Islamlib.com>

Syamsuddin, M. Din. Islam dan Politik Era Orde Baru. Jakarta: Logos, 2000.

Syukur, Abdul. Gerakan Usroh di Indoncsia; Peristiwa Lampung 1989. Yogyakarta: Ombak, 2003.

Tim Pengarusutamaan Gender. Pembaruan Hukum Islam. Counter Legal draft Kompilasi Hukum Islam. Jakarta: TPG DEPAG RI, 2004.

Turmudi, Endang, and Riza Sihbudi (eds). Islam dan Radikalisme di Indonesia. Jakarta: LIPI Press, 2005.

Vatikiotis, Michael R.J. Indonesian Politics Under Suharto. London and New York: Routledge, 1998.

Weber, Robert Philip. "Content Analysis," Clive Seale (ed.), Social Rescarch Methods: Reader. London and New York: Rouletdge, 2004.

Wildan, Muhammad. Students and Politics: The Response of The Pelajar Islann Indoncsia (PII) to Politics in Indonesia. M.A. Thesis, Islamic Studies, Leiden University, 1999.

Young, Iris Marion. Inclusion and Democracy, New York: Oxford University Press, 2000.

Yunanto, etal. Gerakan Militan Islam di Indonesia dan di Asia Tenggara Jakarta: Friedrich-Ebert-Stiftung (FES) and The Ridep Institutc, 2003.

Zada, Khamami. Islam Radikal; Pergulatan Ormas-Ormas Islam Garis Kcras di Indonesia. Jakarta: Teraju, 2002.

Interviews:

Ilutapea, Rivai. Intervicw, 26 April 2005.

Muttaqin, Zainal. Interview, 30 June 2005.

- Interview, 3 June. 2005

Nurdi, Herry. Intcrview, 26 April 2005.

Ridwan, M. Nurkholis. Intervicw. 26 May 2005.

Salman, M.U. Interview. 15 March 2005.

Uki. Interview. 26 May 2005

Sabili Magazines:

Sabili no. 1, VI: 30 June 1998.

Sabili no. 3, VI: 14 August 1998.

Sabili no. 4, VI; 2 September 1998.

Sabilino. 5, VI: 16 September 1998.

Sabilino. 7, VI: 14 October 1998. 
Sabilino. 13, VI: 6 January 1999.

Sabili no. 14, VI: 20 January 1999.

Sabili no. 16, VI: 24 February 1999.

Sabili no. 22, VI: 19 May 1999.

Sabili no. 2, VII: 14 July 1999.

Sabili no. 5, VII: 25 August 1999.

Sabili no. 9, V11: 20 Octobcr 1999.

Sabili no. 10, VII: 3 November 1999.

Sabili no. I1, VII: 17 November 1999.

Sabili no. 1, IX: 4 July 2000.

Sabili no.3, VIII: 26 July 2000.

Sabili no.5, VIII: 23 Augusts 2000.

Sabili no. 8, VIII: 4 October 2000.

Sabili no. 10, VIII: 1 November 2000.

Sabili no. 11, VIII: 15 November 2000.

Sabili no. 16, IX: 31 January 2001.

Sabili no. 18, III: 28 February 2001.

Sabili no. 20 VIII 28 March 2001.

Sabili. no. 25, VIII: 6 June 2001 .

Sabili no. 5. IX: 29 August 2001.

Sabili no. 7, IX: 26 September 2001.

Sabili no.15, IX: 25 January 2002.

Sabili no. 16, IX: 8 February 2002.

Sabili no. 20, IX: 4 April 2002.

Sabili no. 24, IX: 24 May 2002.

Sabili no. 25. IX 13 June 2002.

Sabili no. 26, IX: 27 June 2002.

Sabili no. 11, X: 12 December 2002

Sabilino.11, X: 26 December 2002.

Sabili no.19, X: 10 April 2003.

Sabili no.12, X: 2 January 2003.

Sabilino. 19, X: 10 April 2003.

Sabilino.23, X: 5 June 2003.

Sabili no. 25, X: 3 July 2003.

Sabili no. 2, XI: 14 August 2003.

Sabili no. 4, XI: 11 Scptember 2003

Sabili no. 7, IX : 23 October 2003.

Sabilino. 11, XI: 18 December 2003.

Sabili no. 13, XI: 15 January 2004.

Sabili no. 18, XI: 26 March 2004.

Sabili no. 25, XI: 2 July 2004.

Sabili no. 8, XII: 5 November 2004.

Sabili no. 10, XII: 3 December 2004.

This article was taken from the authors Mastcrs thesis for the Interdisciplinary Islamic Studies Program at the Statc Islamic University Syarif Hidayatullah Jakarta. 